\title{
Patterns of institutional change - the case of accounting regulation in BRICS countries
}

\author{
Julie Thies* \\ Department of Business Administration, Accounting and Control, \\ University of Bremen, \\ Max-von-Laue-Straße 1, 28359 Bremen, Germany \\ Fax: +49-(421)-98-218-666-80 \\ Email: j.thies@uni-bremen.de \\ *Corresponding author
}

\section{Sebastian Andreas Tideman}

Department of Business Administration,

Accounting, Auditing and Sustainability,

University of Hamburg, Germany

Email: sebastian.tideman@uni-hamburg.de

and

Whitman School of Management,

Syracuse University,

721 University Ave, Syracuse, NY 13244, USA

\section{Jochen Zimmermann}

Department of Business Administration, Accounting and Control, University of Bremen,

Max-von-Laue-Straße 1, 28359 Bremen, Germany

Email: jzimmermann@uni-bremen.de

\begin{abstract}
This leximetric study covers trends in a broad range of disclosure and enforcement activities in Brazil, Russia, India, China and South Africa (BRICS) countries from 1991 to 2017. Using institutional theory, we find increasing similarities between the five countries, explained by isomorphism. We also distinguish a pattern between the countries' use of disclosure and enforcement regulation. Disclosure leads enforcement, and enforcement remains less intense and more varied. Institutional rigidities and associated costs serve as an explanation.
\end{abstract}

Keywords: BRICS; accounting regulation; disclosure; enforcement; emerging economies; institutional change patterns.

Reference to this paper should be made as follows: Thies, J., Tideman, S.A. and Zimmermann, J. (2020) 'Patterns of institutional change - the case of accounting regulation in BRICS countries', Int. J. Economics and Accounting, Vol. 9, No. 3, pp.181-220. 
Biographical notes: Julie Thies works as a researcher at the Department of Business Administration, Accounting and Control at the University of Bremen (Germany). She studied at the University of Bremen and at the Udayana University (Indonesia). She graduated from the University of Bremen in 2017 with a Master's in Business Studies. Her main areas of research are related to international accounting, empirical accounting research and accounting in transition economies.

Sebastian Andreas Tideman works as a Postdoctoral Researcher at the Department of Socioeconomics at the University of Hamburg (Germany) and Visiting Researcher at the Syracuse University, New York (USA). After graduating from the University of Bremen in 2014 with a Bachelor's in Business Studies, he worked as a researcher at the Department of Business Administration, Accounting and Control at the University of Bremen and received his Doctoral degree in 2017. His main research interests lie in the fields of sustainability reporting and accounting convergence.

Jochen Zimmermann is a Professor of Business Administration, Accounting and Control at the University of Bremen. He received his Doctoral degree from the University of Mannheim (Germany). His first professorial appointment took him to the London Business School (University of London) from where he left to take up the Chair of Business Administration, Accounting and Control in Bremen. In 2008, he received an Honorary Doctorate from the Tbilisi State University for his commitment in reforming the economic studies. His research interests are international accounting, empirical accounting research, regulation of accounting as well as insurance.

\section{Introduction}

Industrialisation requires emerging economies to access deep and liquid capital markets and to compete with developed countries for investor attention (Armijo, 2007; Ghio and Verona, 2015; Zeghal and Mhedhbi, 2006). As investors value comparability in their investment decisions and feel more confident in an environment they understand and trust (Meser et al., 2015), emerging economies face a demand for comparable and decision-relevant accounting information. We posit that emerging economies regulate accounting to provide such information in a specific way: they first adapt their disclosure system and then follow up with changes in enforcement. A spotlight is the case of adopting international reporting standards (Ball, 2006; Daske et al., 2013); but accounting regulation goes well beyond prescribing financial reporting rules. Disclosure regulation will not only lead enforcement. As stronger enforcement is associated with substantial difficulties, as highlighted by the study of Carneiro et al. (2017), we therefore expect that enforcement activity is not only slower but also on a lower level than disclosure efforts.

We focus on BRICS as newly industrialised countries ${ }^{1}$, since they provide a unique setting. The BRICS countries play a central and crucial role in the global flows of goods and services. For instance, BRICS countries have more comprehensive stock exchanges compared to other newly industrialised markets, such as Indonesia, Mexico or Turkey (Nnadi and Tanna, 2019). At the same time, these countries have also proven to be quite resilient to global macroeconomic shocks (Makin and Arora, 2014). However, a further common characteristic for these countries are their institutional voids, sometimes 
culminating in a total absence of regulation (Doh et al., 2017). In this study, we analyse how accounting regulation has changed in these countries over time. We conduct this examination in two steps: First, we identify the special circumstances regarding the countries' institutional settings and second, we use a scoring model to assess regulatory changes in disclosure and enforcement regulation of BRICS countries.

We use a wide measure of accounting regulation. Previous studies show that not only the adoption of international accounting standards such as IFRS is important but also other disclosures on governance issues like inside ownership, executive compensation, as are enforcement issues like the level of government involvement in supervisory authorities, or sanctions of management malpractice (Bushman et al., 2004; Holthausen, 2009; La Porta et al., 2006). We therefore use ten items each for disclosure and enforcement, all building on prior literature (Abée et al., 2019; Meser et al., 2015; Zimmermann and Tideman, 2017). The mean value of all ten items per year is aggregated into a score that shows differences between countries over time. With this method, we make the regulatory effort of a country quantifiable and comparable. Using institutional theory, we find that the countries' regulation becomes stronger and more similar over time and enforcement regulation is at a lower level than disclosure regulation.

The aim of this study is to contribute to the debate on accounting regulation in newly industrialised economies, and a general lack of a holistic view on accounting regulation in these countries. We add to the literature in three ways: First, we are the first to leximetrically measure regulatory differences between emerging countries (e.g., BRICS countries). Accounting literature has limited the scope to developed countries so far (Abée et al., 2019; Baker and Barbu, 2007; Ding et al., 2007; Meser et al., 2015; Zimmermann and Tideman, 2017). Second, we provide evidence that BRICS countries have increased disclosure and enforcement regulations, but to a different extent. To our knowledge we are the first who give a comprehensive picture for accounting regulation including both disclosure and enforcement for emerging markets.

The remainder of this paper is structured as follows: Section 2 reviews the extant literature on the institutional settings and accounting regulation in BRICS countries. Furthermore, we develop our expectations of the development of disclosure and enforcement levels in BRICS countries. Section 3 addresses the data sources and describes the measurement of disclosure and enforcement scores. Our results and its discussion are presented in Section 4, and Section 5 concludes.

\section{Literature review}

\subsection{Institutional settings and isomorphism}

The BRICS countries diverge in their cultural backgrounds ${ }^{2}$ (Cowperthwaite, 2010; Gray, 1988; Hofstede, 1980), do not speak a common language, and their economic structures also differ (Ghio and Verona, 2015). However, they share common features that justify the BRICS as an analytical category of nations - concerning their economic development they exceeded growth compared to developed markets (Biggemann and Fam, 2011). Besides their growth patterns, BRICS countries also commonly lack a stable institutional environment (Schuster, 2006).

The absence of stable and developed institutions is one of the key characteristics in distinguishing between newly industrialised markets and developed markets (Doh et al., 
2017). Studies provide evidence that the existence of formal institutions matters for economic performance and affect the propensity of investing in a specific country (Acemoglu et al., 2001, 2002; La Porta et al., 1997, 1998). Gaps in the legal system lead to a lack of reliable information, indicate poor investor protection and less effectual enforcement mechanisms (La Porta et al., 1999, 2000, 1998). Consequences show in a loss of investors trust because of reduced financial transparency (Fan et al., 2011) or higher corruption levels (Houqe and Monem, 2016). A poor institutional environment therefore imposes additional costs for investors and higher risk premiums (Khanna and Palepu, 1997; Shleifer and Vishny, 1993). Risk premiums also associate ceteris paribus with investment flows, and many papers have revealed rather a positive relationship between the quality of a country's institutional setting and investment flows (Aizenman and Spiegel, 2006; Alfaro et al., 2005; Hyun, 2006; Wei, 2000). All studies imply that the institutional setting in terms of accounting regulation matters for the emerging markets' economic performance.

There are numerous theories that have been used to explain the adoption of international accounting regulations by emerging countries. For example, Mir and Rahaman (2005) used institutional theory to explain the adoption of international accounting regulation in Bangladesh. Kim (2016) used a neo-institutional framework to explain the impact of international accounting regulations on the reporting quality of Russian firms. Venard and Hanafi (2008) also rely on neo-institutional theory and focus on the link between corruption and organisational isomorphism in financial institutions in emerging countries. A holistic view is given in Doh et al. (2017); they explain that in emerging markets institutional voids matters for the quality of adaptional processes in accounting. Equity theory was used by Rodrigues et al. (2012) to explain the influences on the development of accounting regulations in Brazil. Peng and van der Laan Smith (2010) used teleology theory to investigate the changes in Chinese GAAP over time. Another theoretical approach is given in the study of Lassou and Hopper (2016), who built on political economy as underlying theory in explaining the accounting reform in an ex-French African colony. Brown et al. (2014) used capital markets theory and focused on audit and accounting enforcement and the effect on the quality of financial information available in capital markets.

A common denominator for these studies is that history and institutions matter. This is, in our view, most generally referred in institutional theory as elaborated by Scott (1987), North (1990) and DiMaggio and Powell (1983) among others. Institutional theory provides a theoretical lens to investigate accounting change in BRICS countries because it can provide explanations for the adaptation of particular practices (Deegan, 2014). North (1990) defines institutions as the 'rules of the game' in a society that shape human interaction. In consequence, they structure incentives in human exchange, be it political, social, or economic. Accounting itself can be regarded as a complementary institution which co-evolves with the more general or underlying institutional structure of the entire socio-economic system (Zimmermann and Werner, 2013). Institutional theory can explain system changes by exogenous shocks or challenges. They trigger processes of adaptation that eliminate or reduce differences between institutional arrangements. DiMaggio and Powell (1983) adopt the term isomorphism from the natural sciences to describe and explain such processes. Isomorphic change accordingly defines the alignment of different institutional paths. In the broader sense, isomorphism is also related to the concept of convergence (Rodrigues and Craig, 2007). 


\subsection{Accounting regulation in BRICS countries}

The main underlying motivation of liberalisation and deregulation is to open up financial markets, which should result in efficiency and welfare gains for the economies involved. Most emerging markets have become more integrated in recent years through liberalisation and deregulation of the stock markets, improvements of their institutional infrastructure and through the development of more efficient communication technologies. Increasing regulation is a result from the globalisation of goods and financial markets on the one hand and a response to financial crises on the other (Zimmermann et al., 2008). Yet, accounting regulation has not followed the deregulation trends that are present in many sectors of emerging markets (Franke, 2000). The following section provides highlights of these regulatory processes.

One of the major areas of accounting regulation is the adoption of international accounting standards. The BRICS countries have made reporting under IFRS mandatory or use national GAAP geared to international accounting regulation (Ghio and Verona, 2015; Nobes and Zeff, 2008). In Brazil, IFRS are mandatory for consolidated financial statements of listed companies for financial years ending on or after 31st December 2010 (Carneiro et al., 2017). The Law on Consolidated Accounts (LoCA), signed in 2010, introduced the requirements for the use of IFRS for consolidated financial statements in Russia as of 2012 (Ghio and Verona, 2015). Sharma et al. (2017) provided evidence that India had a stepwise integration of international accounting standards. From 2010 to 2016 listed firms had the opportunity to submit their financial statements either in accordance to the accounting standards specified in the Companies Law Art. 211 (3) c or with IFRS. In January 2015, the Indian Ministry of Corporate Affairs (MCA) released a revised roadmap that reflects that companies with a net worth of Rs. 500 crore (approximately USD 71 million) or more will have to mandatorily follow Indian Accounting Standards (Ind AS), which are largely converged with IFRS, from 1st April 2016 (Borker, 2012; MCA, 2015). The Chinese accounting harmonisation process is somewhat different. China's Ministry of Finance moved Chinese GAAP towards convergence with IFRS on the one hand through the direct import of standards from IFRS and on the other through fundamental changes in Chinese GAAP (Peng and van der Laan Smith, 2010). In South Africa, the option to use either SA GAAP or IFRS existed from 1995 (Prather-Kinsey, 2006) until 2012. Since then only IFRS are allowed. Daske et al. (2008) linked the adoption of IFRS to institutional commitment but also coined the term 'label adoption'. The phenomenon of label adopting occurs when countries use internationally accepted regulations only for reputational purposes and do not fully commit to them (Guerreiro et al., 2012a, 2012b). This will become evident in the enforcement actions taken by the respective nations.

According to Meser et al. (2015), disclosure is not limited to the introduction of international accounting standards like IFRS or US GAAP. It includes all information an entity provides to the interested public. They subdivided the area of disclosure into financial disclosures and governance disclosures. Financial disclosures include besides the use of international accounting standards further reporting elements like the complexity of management reports or the frequency of interim reporting. Then again, governance disclosures comprise all information published that goes beyond the financial reporting itself. These forms of disclosure refer to firm's disclosure on characteristics that ensure that agents are held liable, e.g., the reporting on inside ownership or related party transactions. In Table 1, we present our measurement approach for disclosure regulation. 
Again, we provide only a brief overview and refer for details to Tables 3 to 7 . In China, India and South Africa binding regulations concerning a management commentary exist, whereas Brazil and Russia require only limited disclosure or recommend it on a voluntary level. Disclosure requirements regarding material information, quarterly reports and segment information are - except for South Africa - on a same level. For compensation and inside ownership, only Brazilian companies have to report aggregated values for both. In Russia, the aggregated disclosure of management compensation is required, and in China, the aggregated disclosure of inside ownership. All countries have to prepare a prospectus for any public offering; in Russia some material exemptions exist. With the exception of China, countries require the disclosure of detailed shareholder information.

Table 1 Description of the disclosure score

\begin{tabular}{|c|c|c|}
\hline \multicolumn{3}{|c|}{ Disclosure score } \\
\hline \multicolumn{2}{|c|}{ Score items } & \multirow{2}{*}{ Description } \\
\hline \multicolumn{2}{|c|}{ Financial disclosures } & \\
\hline D1 & $\begin{array}{l}\text { Information } \\
\text { accounting }\end{array}$ & $\begin{array}{l}\text { Equals } 1 \text { if companies are required to follow international } \\
\text { accounting standards for their consolidated financial statements; } \\
\text { equals } 0.5 \text { if companies have the choice between local GAAP } \\
\text { and international accounting standards; equals } 0 \text { otherwise. }\end{array}$ \\
\hline D2 & $\begin{array}{l}\text { Management } \\
\text { commentary }\end{array}$ & $\begin{array}{l}\text { Rating for the complexity of the management discussion and } \\
\text { analysis }(M D \& A \text {, as it is named in the USA; e.g., in the UK it is } \\
\text { named operating and financial review, in Germany } \\
\text { Lagebericht). Equals } 1,0.75,0.5,0.25 \text { or if no such report exists } \\
0 \text {. }\end{array}$ \\
\hline D3 & $\begin{array}{l}\text { Material } \\
\text { information }\end{array}$ & $\begin{array}{l}\text { Equals } 1 \text { if companies are required to pursue ad hoc disclosure; } \\
\text { equals } 0 \text { otherwise. }\end{array}$ \\
\hline D4 & Quarterly reports & $\begin{array}{l}\text { Equals } 1 \text { if companies are required to publish quarterly reports; } \\
\text { equals } 0.5 \text { if reports have to be published semi-annually; equals } \\
0 \text { otherwise. }\end{array}$ \\
\hline D5 & $\begin{array}{l}\text { Segment } \\
\text { information }\end{array}$ & $\begin{array}{l}\text { Equals } 1 \text { if companies are required to publish detailed } \\
\text { information on business segments and regional segments; equals } \\
0.5 \text { if companies are free to choose the extent of segment } \\
\text { information disclosure; equals } 0 \text { otherwise. }\end{array}$ \\
\hline \multicolumn{3}{|c|}{ Governance disclosures } \\
\hline D6 & Compensation & $\begin{array}{l}\text { Equals } 1 \text { if companies are required to disclosure total } \\
\text { compensation of each top manager; equals } 0.5 \text { if regulation only } \\
\text { requires the disclosure of the aggregate compensation of top } \\
\text { management; equals } 0 \text { otherwise. }\end{array}$ \\
\hline D7 & Inside ownership & $\begin{array}{l}\text { Equals } 1 \text { if firms are required to disclose the number of shares } \\
\text { owned by each member of the management; equals } 0.5 \text { if } \\
\text { regulation only requires the aggregate number of the shares } \\
\text { owned by the management to be disclosed; equals } 0 \text { otherwise. }\end{array}$ \\
\hline
\end{tabular}

Source: Taken from Zimmermann and Tideman (2017), based on Meser et al. (2015) 
Table 1 Description of the disclosure score (continued)

\begin{tabular}{|c|c|c|}
\hline \multicolumn{3}{|c|}{ Disclosure score } \\
\hline \multicolumn{2}{|c|}{ Score items } & \multirow{2}{*}{ Description } \\
\hline \multicolumn{2}{|c|}{ Governance disclosures } & \\
\hline D8 & Prospectus & $\begin{array}{l}\text { Equals } 1 \text { if companies are required to setup a prospectus for } \\
\text { potential investors on any public offering; equals } 0.5 \text { if there } \\
\text { exist material exemptions from publishing a prospectus, e.g., } \\
\text { regarding tender size; equals } 0 \text { otherwise. }\end{array}$ \\
\hline D9 & Shareholders & $\begin{array}{l}\text { Equals } 1 \text { if companies are required to disclose details (e.g., } \\
\text { name, share property) of shareholders that directly or indirectly } \\
\text { control at least } 10 \% \text { of the company's stock; equals } 0.5 \text { if } \\
\text { regulation only requires the disclosure of the direct or aggregate } \\
\text { ownership of these shareholders; equals } 0 \text { otherwise. }\end{array}$ \\
\hline D10 & Transactions & $\begin{array}{l}\text { Equals } 1 \text { if companies are required to disclosure all capital } \\
\text { market transactions that involve related parties; equals } 0.5 \text { if } \\
\text { only some transactions between the company and related parties } \\
\text { have to be disclosed; equals } 0 \text { otherwise. }\end{array}$ \\
\hline \multicolumn{2}{|c|}{ Disclosure score value } & $\begin{array}{l}\text { Calculated as the average of items D1 to D10 and ranges } \\
\text { between } 0 \text { and } 1\end{array}$ \\
\hline
\end{tabular}

Source: Taken from Zimmermann and Tideman (2017), based on Meser et al. (2015)

Comparable developments are present in the BRICs countries' enforcement. Generally speaking, enforcement includes all mechanisms that ensure compliance with disclosure requirements. Many studies argue that the extent to which disclosure regulations are enforced and violations prosecuted is as important as the disclosure requirements themselves (Ball, 2001, 2006; Ball et al., 2003; Berkowitz et al., 2003; Burgstahler et al., 2006; Durnev and Kim, 2005; Francis et al., 2005; Hope et al., 2006; Sunder, 1997). Our lexicographic analysis will separate enforcement into issues of independence and scope, which are presented in more detail in Tables 3 to 7 . Independence refers to the absence of direct government involvement, whether the supervision is conducted by distinct authorities (La Porta et al., 2006), and what rulemaking powers are vested in them. Scope addresses the range of actions that the enforcement system is entitled to carry out. These items primarily capture a supervisor's capacity to launch investigations and to impose sanctions (Meser et al., 2015). We present the measurement approach for enforcement in Table 2 .

Already Zeff and Nobes (2010) have observed that countries have implemented different enforcement mechanisms. For example, the appointment of executive board members of enforcement agencies is still made by the government or other executive institutions in Brazil, China and Russia. Except for Russia, the supervision of commercial banks and stock exchanges (focus) is done by independent agencies. All enforcement institutions of the regarded countries up to South Africa have the opportunity to setup establish regulations (rule-making power) on public offerings and stock exchange listing rules without approval from other governmental institutions. Apart from Brazil, the government of all other countries can dismiss members of the enforcement agencies. The situation is similar regarding the enforcement review process. With the exception of South Africa, only a reactive review is statutory. 
Table 2 Description of the enforcement score

\begin{tabular}{|c|c|c|}
\hline \multicolumn{3}{|c|}{ Enforcement score } \\
\hline \multicolumn{2}{|c|}{ Score items } & \multirow{2}{*}{ Description } \\
\hline \multicolumn{2}{|c|}{ Independence } & \\
\hline E1 & Appointment & $\begin{array}{l}\text { Equals } 1 \text { if the executive board members of the enforcement } \\
\text { agency at the state or federal level (hereinafter termed 'the } \\
\text { Enforcement Institution') are not exclusively appointed by the } \\
\text { executive (e.g., the government or any other executive institution); } \\
\text { equals } 0 \text { otherwise. }\end{array}$ \\
\hline E2 & $\begin{array}{l}\text { Auditor's } \\
\text { independence }\end{array}$ & $\begin{array}{l}\text { Equals } 1 \text { if substantial laws concerning the independence of } \\
\text { auditors are established; equals } 0.5 \text { if there are only weak } \\
\text { independence criteria; equals } 0 \text { otherwise. }\end{array}$ \\
\hline E3 & Focus & $\begin{array}{l}\text { Equals } 1 \text { if separate government agencies or official authorities are } \\
\text { in charge of supervising commercial banks and stock exchanges; } \\
\text { equals } 0 \text { otherwise. }\end{array}$ \\
\hline E4 & $\begin{array}{l}\text { Rule-making } \\
\text { power }\end{array}$ & $\begin{array}{l}\text { Equals } 1 \text { if the Enforcement Institution can establish regulations } \\
\text { on public offerings and stock exchange listing rules without } \\
\text { approval from other governmental institutions; equals } 0.5 \text { if the } \\
\text { Enforcement Institution can establish regulations on public } \\
\text { offerings and stock exchange listing rules only with approval from } \\
\text { other governmental institutions; equals } 0 \text { otherwise. }\end{array}$ \\
\hline E5 & Tenure & $\begin{array}{l}\text { Equals } 1 \text { if the governmental authority that appoints members of } \\
\text { the Enforcement Institution does not have the power to dismiss } \\
\text { them; equals } 0 \text { otherwise. }\end{array}$ \\
\hline \multicolumn{3}{|c|}{ Scope } \\
\hline E6 & Document & $\begin{array}{l}\text { Equals } 1 \text { if the Enforcement Institution has the legal power to } \\
\text { demand documents from all persons that are related to the } \\
\text { suspicious firm; equals } 0.5 \text { if the Enforcement Institution has the } \\
\text { legal power to only demand documents from the directors of } \\
\text { suspicious publicly-traded corporations; equals } 0 \text { otherwise. }\end{array}$ \\
\hline E7 & Review & $\begin{array}{l}\text { Equals } 1 \text { if the Enforcement Institution requires a continuous filing } \\
\text { of disclosure documents and submits them to a systematic, } \\
\text { proactive review; equals } 0.5 \text { if a filing and only a reactive review } \\
\text { is statutory, equals } 0 \text { otherwise. }\end{array}$ \\
\hline E8 & $\begin{array}{l}\text { Sanctions } \\
\text { company }\end{array}$ & $\begin{array}{l}\text { Equals } 1 \text { if the Enforcement Institution has far reaching } \\
\text { competencies to impose financial and other legal penalties against } \\
\text { companies; equals } 0.5 \text { if the Enforcement Institution can only } \\
\text { impose financial penalties; equals } 0 \text { otherwise. }\end{array}$ \\
\hline E9 & $\begin{array}{l}\text { Sanctions } \\
\text { management }\end{array}$ & $\begin{array}{l}\text { Equals } 1 \text { if accountants/managers can be held criminally liable } \\
\text { when they are unaware of fraud and misleading information; } \\
\text { equals } 0.5 \text { if the accountants/managers can be held criminally } \\
\text { liable when they are aware that the financial statements are } \\
\text { misleading; equals } 0 \text { otherwise. }\end{array}$ \\
\hline E10 & $\begin{array}{l}\text { Sworn } \\
\text { statement }\end{array}$ & $\begin{array}{l}\text { Equals } 1 \text { if the directors have to sign for the material accuracy of } \\
\text { financial statements; equals } 0 \text { otherwise. }\end{array}$ \\
\hline \multicolumn{2}{|c|}{$\begin{array}{l}\text { Enforcement score } \\
\text { value }\end{array}$} & $\begin{array}{l}\text { Calculated as the average of items E1 to E10 and ranges between } \\
0 \text { and } 1\end{array}$ \\
\hline
\end{tabular}

Source: Taken from Zimmermann and Tideman (2017), based on Meser et al. (2015) 
Institutional theory would predict that competition for capital will elicit a response from the accounting system and disclosure and enforcement regulations will increase and becomes more similar over time. In our measurement model, changes are registered as fulfilling demands on disclosure and enforcement, which have been previously identified in the literature. An 'optimal' response is a full provision of the disclosure and enforcement items enumerated in Tables 1 and 2. We expect a later and smaller effect of enforcement than for disclosure due to two reasons: One, disclosure regulation can be easy-to-achieve label adoption. Its adverse effects of weak institutions set in and easy benefits from disclosure are crowded out, enforcement is stepped up. Thus enforcement changes occur later as they underpin previous disclosure changes and two, the changes are smaller, because from the relevant literature we know that effort in enforcement is more costly (Doh et al., 2017) and we therefore expect a lower increase in the enforcement as compared to disclosure level (Ball, 2006; Mahoney, 2009).

\section{Method}

Our scoring method for measuring the disclosure and enforcement requirements draws on prior research. We capture disclosure and enforcement items using leximetrics, which is a method of quantitative legal research. Since La Porta et al. (1998), leximetrics has also established itself as a method of empirical capital market and accounting research. Following La Porta et al. (2006), Meser et al. (2015), Zimmermann and Tideman (2017) and Abée et al. (2019), our scores comprise ten items each for disclosure and enforcement, which range between 0 and 1, where a value of 0 represented the absence and a value of 1 the highest possible regulation intensity of the element. We change score values in the time series whenever a regulatory measure takes effect legally. Both indices were then calculated as equally weighted averages of all ten individual elements and consequently ranged between 0 and 1 over time. The accounting regulation score by Zimmermann and Tideman (2017) built on disclosure scores and enforcement scores developed by La Porta et al. (2006) and Meser et al. (2015). Meser et al. (2015) enhanced the disclosure and enforcement items made by La Porta et al. (2006) by integrating further elements into the score that were missing in their study, such as information accounting, management commentary, material information, quarterly report, segment reporting, auditor independence, and sworn statement.

The most straightforward way to achieve the best level of in disclosure and enforcement in our analysis is to reach a level of 1 in the overall items. For this reason, we do not need a test group or benchmark country, because the ideal level is set to 1 . 
Table 3 Score values by year, Brazil

\begin{tabular}{|c|c|c|c|c|c|c|c|c|c|c|}
\hline & & 1991 & 1992 & 1993 & 1994 & 1995 & 1996 & 1997 & 1998 & 1999 \\
\hline D1 & $\begin{array}{l}\text { Information } \\
\text { accounting }\end{array}$ & 0 & 0 & 0 & 0 & 0 & 0 & 0 & 0 & 0 \\
\hline D2 & $\begin{array}{l}\text { Management } \\
\text { commentary }\end{array}$ & $0.25^{\mathrm{b}}$ & 0.25 & 0.25 & 0.25 & 0.25 & 0.25 & 0.25 & 0.25 & 0.25 \\
\hline D3 & $\begin{array}{l}\text { Material } \\
\text { information }\end{array}$ & $1^{\mathrm{c}}$ & 1 & 1 & 1 & 1 & 1 & 1 & 1 & 1 \\
\hline D4 & $\begin{array}{l}\text { Quarterly } \\
\text { reports }\end{array}$ & 0 & 0 & 0 & 0 & 0 & 0 & 0 & 0 & 0 \\
\hline D5 & $\begin{array}{l}\text { Segment } \\
\text { information }\end{array}$ & 0.5 & 0.5 & 0.5 & 0.5 & 0.5 & 0.5 & 0.5 & 0.5 & 0.5 \\
\hline D6 & Compensation & 0 & 0 & 0 & 0 & 0 & 0 & $0.5^{\mathrm{f}}$ & 0.5 & 0.5 \\
\hline D7 & $\begin{array}{l}\text { Inside } \\
\text { ownership }\end{array}$ & $0.5^{\mathrm{g}}$ & 0.5 & 0.5 & 0.5 & 0.5 & 0.5 & 0.5 & 0.5 & 0.5 \\
\hline D8 & Prospectus & $1^{\mathrm{h}}$ & 1 & 1 & 1 & 1 & 1 & 1 & 1 & 1 \\
\hline D9 & Shareholders & 0 & 0 & 0 & 0 & 0 & 0 & 0 & 0 & 0 \\
\hline $\mathrm{D} 10$ & Transactions & 0 & 0 & 0 & 0 & 0 & 0 & 0 & 0 & 0 \\
\hline \multirow{2}{*}{\multicolumn{2}{|c|}{ Disclosure score }} & 0.33 & 0.33 & 0.33 & 0.33 & 0.33 & 0.33 & 0.38 & 0.38 & 0.38 \\
\hline & & 2000 & 2001 & 2002 & 2003 & 2004 & 2005 & 2006 & 2007 & 2008 \\
\hline D1 & $\begin{array}{l}\text { Information } \\
\text { accounting }\end{array}$ & 0 & 0 & 0 & 0 & 0 & 0 & 0 & $0.5^{\mathrm{a}}$ & 0.5 \\
\hline
\end{tabular}

Notes: a ${ }^{\mathrm{CPC}}$ is the Brazilian standard-setting body that approves all IFRS Standards for application in Brazil as they are issued by the IASB following the terms of a Memorandum of Understanding among CPC, IFRS Foundation, and CFC (the Brazilian Accountants Body). Firms are allowed to voluntarily disclose their financial statements according to IFRS since 2007. Since 2010, listed companies have to disclose their financial statements applying IFRS (Rodrigues et al., 2012); Comissão de Valores Mobiliários (CVM - Instruction 457, Art. 1-2 of July 13th, 2007).

bListed companies are required to disclose investments in related and controlled companies as well as the changes of these investments in their management report since 1976. Since there is no further information required, the score value is set to 0.25 for the entire observation period (Law 6.404/76, Art. 243).

'Each listed company has to disclose important information immediately, which may have potentially impacts to the firms' share price (Law 6.404/76, Art. 157

(4)). There are no changes over the sample period.

fListed companies were committed to disclose management fees either on an individual or aggregated base until 2010 (Law 6.404/76, Art. 152, text as determined by Law 9.457/97). This regulation has been modified: Since the beginning of the financial year 2010, companies have to disclose the Reference Form document (Formulário de Referência - FR), which contains the minimum, mean and maximum salaries of senior management and the board of directors. [Barros et al., (2015); CVM Instruction 480, Annex 24 of December 7th, 2009]. gA manager has to state his ownership interest in the company as well as the shares of other companies held which are controlled by the main company upon signing the certificate of appointment (Law 6.404/76, Art. 157(1)).

${ }^{\mathrm{h}}$ The general requirement to disclose a prospectus is prescribed in an unchanged way in Law 6.404/76, Art. 82. 
Table 3 Score values by year, Brazil (continued)

\begin{tabular}{|c|c|c|c|c|c|c|c|c|c|c|}
\hline & & 2000 & 2001 & 2002 & 2003 & 2004 & 2005 & 2006 & 2007 & 2008 \\
\hline D2 & $\begin{array}{l}\text { Management } \\
\text { commentary }\end{array}$ & 0.25 & 0.25 & 0.25 & 0.25 & 0.25 & 0.25 & 0.25 & 0.25 & 0.25 \\
\hline D3 & $\begin{array}{l}\text { Material } \\
\text { information }\end{array}$ & 1 & 1 & 1 & 1 & 1 & 1 & 1 & 1 & 1 \\
\hline D4 & $\begin{array}{l}\text { Quarterly } \\
\text { reports }\end{array}$ & 0 & 0 & 0 & 0 & 0 & 0 & 0 & 0 & 0 \\
\hline D5 & $\begin{array}{l}\text { Segment } \\
\text { information }\end{array}$ & 0.5 & 0.5 & 0.5 & 0.5 & 0.5 & 0.5 & 0.5 & 0.5 & 0.5 \\
\hline D6 & Compensation & 0.5 & 0.5 & 0.5 & 0.5 & 0.5 & 0.5 & 0.5 & 0.5 & 0.5 \\
\hline D7 & $\begin{array}{l}\text { Inside } \\
\text { ownership }\end{array}$ & 0.5 & 0.5 & 0.5 & 0.5 & 0.5 & 0.5 & 0.5 & 0.5 & 0.5 \\
\hline D8 & Prospectus & 1 & 1 & 1 & 1 & 1 & 1 & 1 & 1 & 1 \\
\hline D9 & Shareholders & 0 & 0 & 0 & 0 & 0 & 0 & 0 & $1^{\mathrm{i}}$ & 1 \\
\hline D10 & Transactions & 0 & 0 & 0 & 0 & 0 & 0 & 0 & 0 & $1^{\mathrm{j}}$ \\
\hline \multirow{2}{*}{\multicolumn{2}{|c|}{ Disclosure score }} & 0.38 & 0.38 & 0.38 & 0.38 & 0.38 & 0.38 & 0.38 & 0.53 & 0.63 \\
\hline & & 2009 & 2010 & 2011 & 2012 & 2013 & 2014 & 2015 & 2016 & 2017 \\
\hline D1 & $\begin{array}{l}\text { Information } \\
\text { accounting }\end{array}$ & 0.5 & 1 & 1 & 1 & 1 & 1 & 1 & 1 & 1 \\
\hline D2 & $\begin{array}{l}\text { Management } \\
\text { commentary }\end{array}$ & 0.25 & 0.25 & 0.25 & 0.25 & 0.25 & 0.25 & 0.25 & 0.25 & 0.25 \\
\hline D3 & $\begin{array}{l}\text { Material } \\
\text { information }\end{array}$ & 1 & 1 & 1 & 1 & 1 & 1 & 1 & 1 & 1 \\
\hline D4 & $\begin{array}{l}\text { Quarterly } \\
\text { reports }\end{array}$ & 0 & $1^{\mathrm{d}}$ & 1 & 1 & 1 & 1 & 1 & 1 & 1 \\
\hline
\end{tabular}

Notes: ${ }^{\mathrm{d}} \mathrm{CVM}$ Instruction 480, Art. 29 requires listed companies to publish quarterly reports. This provision came into force on December 7th, 2009 for reporting periods starting on January, 1st 2010 (Cissé et al., 2012).

iSince the amendment of CVM Instruction 358, Art. 12 with CVM Instruction 449 July 15th, 2007, there is an obligation to disclose information on persons or groups of persons with a shareholding of at least $5 \%$ of the voting shares who are able to exercise direct or indirect control of the company. The requirements are closely specified in CVM Instruction 358, Art. 12, item 2 which is introduced with the CVM Instruction 449 of July 15th, 2007. The company has to declare the objective of the participation and quantity envisaged, including a declaration of the buyer that purchases will not alter the composition of the control or administrative structures of the company.

jThe Standard Comitê de Pronunciamentos Contábeis (CPC) 05 was published within the effort of the convergence of Brazilian GAAP and IFRS in 2008. It deals with the regulation of company transactions with related parties. There are no significant differences to International Accounting Standard (IAS) 24. The matter is now regulated by Annex 30-XXXIII introduced by CVM Instruction 552 of October 9th, 2014. Among other provisions, CVM instruction 552 amended CVM Instruction 480 of December 7th, 2009. The purpose of Annex 30-XXXIII is to allow shareholders of the issuer to monitor the most relevant transactions more closely and immediately. The term 'issuer' also comprises companies directly or indirectly controlled by the issuer. 
Table 3 Score values by year, Brazil (continued)

\begin{tabular}{llccccccccc}
\hline & & 2009 & 2010 & 2011 & 2012 & 2013 & 2014 & 2015 & 2016 & 2017 \\
\hline D5 & $\begin{array}{l}\text { Segment } \\
\text { information }\end{array}$ & 0.5 & $1^{\mathrm{e}}$ & 1 & 1 & 1 & 1 & 1 & 1 & 1 \\
D6 & $\begin{array}{l}\text { Compensation } \\
\text { D7 }\end{array}$ & 0.5 & 0.5 & 0.5 & 0.5 & 0.5 & 0.5 & 0.5 & 0.5 & 0.5 \\
& $\begin{array}{l}\text { Inside } \\
\text { ownership }\end{array}$ & 0.5 & 0.5 & 0.5 & 0.5 & 0.5 & 0.5 & 0.5 & 0.5 & 0.5 \\
D8 & Prospectus & 1 & 1 & 1 & 1 & 1 & 1 & 1 & 1 & 1 \\
D9 & Shareholders & 1 & 1 & 1 & 1 & 1 & 1 & 1 & 1 & 1 \\
D10 & Transactions & 1 & 1 & 1 & 1 & 1 & 1 & 1 & 1 & 1 \\
\hline Disclosure score & 0.63 & 0.83 & 0.83 & 0.83 & 0.83 & 0.83 & 0.83 & 0.83 & 0.83 \\
\hline & & 1991 & 1992 & 1993 & 1994 & 1995 & 1996 & 1997 & 1998 & 1999 \\
\hline E1 & Appointment & $0^{\mathrm{k}}$ & 0 & 0 & 0 & 0 & 0 & 0 & 0 & 0 \\
E2 & $\begin{array}{l}\text { Auditor } \\
\text { independence }\end{array}$ & 0 & 0 & 0 & 0 & 0 & 0 & 0 & 0 & 1 \\
E3 & Focus & $1^{\mathrm{m}}$ & 1 & 1 & 1 & 1 & 1 & 1 & 1 & 1 \\
E4 & Rule-making & 0 & 0 & 0 & 0 & 0 & 0 & 0 & 0 & 0 \\
& power & & & & & & & & & \\
\hline
\end{tabular}

Notes: eIn Brazil, the disclosure of segment information is a relatively new requirement: it has been compulsory for public companies since 2010. Technical Pronouncement CPC 22 was prepared based on IFRS 8, which regulates such matters and allows for discretion, which can prompt companies to adopt different strategies and exhibit different disclosure levels (Alves e Souza et al., 2016). Prior to CPC 22, there was no standardisation in Brazil for the disclosure of segment reporting. The CVM published a voluntary orientation report recommending that listed companies provide segment-level reporting (UNCTAD, 2008). Therefore, some of the public companies disclosed voluntarily, whereas others disclosed due to the requirements of foreign markets or even regulatory agencies (Alves e Souza et al., 2016). The requirements increased as a result of the obligation to prepare consolidated financial statements in accordance with IFRS. Therefore, the score value is set to 1 starting in year 2010 onwards.

kThe chairman of the supervisory board and four commissioners legally manage the Brazilian securities exchange commission CVM. The members are elected by the president of Brazil in consent with the senate [Rodrigues et al., (2012); Law 6.385/76 Art. 6, text as determined by Law 10.411/02].

'The CVM Instruction 308 Art. 4-6 dated May 14th, 1999 describes the criteria for the independence of the auditor and audit company. According to this instruction, companies have to fulfil various conditions for the registration as an independent auditor.

$\mathrm{m}$ There are three main regulators supervising the financial system in Brazil. The National Monetary Council (CMN) is introduced by Law 4.595/64 as institution with the responsibility to supervise the monetary and currency exchange policies for the purpose of economic and social development of Brazil, as well as operating the Brazilian financial system. The Central Bank has the obligation to assure the purchasing power stability of the national currency and the solidity of the national financial system (Themudo Lessa et al., 2020). The Banking Law granted powers to the Central Bank to implement monetary and credit policies issued by the CMN; Law 4.595/64). CVM takes the supervisory of the stock exchange and was founded in December 1976 (Luna and Klein, 2014). Therefore, the score value is set to 1 over the whole observation period. 
Table 3 Score values by year, Brazil (continued)

\begin{tabular}{|c|c|c|c|c|c|c|c|c|c|c|}
\hline & & 1991 & 1992 & 1993 & 1994 & 1995 & 1996 & 1997 & 1998 & 1999 \\
\hline E5 & Tenure & 0 & 0 & 0 & 0 & 0 & 0 & 0 & 0 & 0 \\
\hline E6 & Document & 0 & 0 & 0 & 0 & 0 & 0 & 0 & 0 & 0 \\
\hline E7 & Review & 0 & 0 & 0 & 0 & 0 & 0 & 0 & 0 & 0 \\
\hline E8 & $\begin{array}{l}\text { Sanctions } \\
\text { company }\end{array}$ & $0.5^{\mathrm{r}}$ & 0.5 & 0.5 & 0.5 & 0.5 & 0.5 & 1 & 1 & 1 \\
\hline E9 & $\begin{array}{l}\text { Sanctions } \\
\text { management }\end{array}$ & $1^{\mathrm{s}}$ & 1 & 1 & 1 & 1 & 1 & 1 & 1 & 1 \\
\hline E10 & $\begin{array}{l}\text { Sworn } \\
\text { statement }\end{array}$ & $1^{\mathrm{t}}$ & 1 & 1 & 1 & 1 & 1 & 1 & 1 & 1 \\
\hline \multirow{2}{*}{\multicolumn{2}{|c|}{ Enforcement score }} & 0.35 & 0.35 & 0.35 & 0.35 & 0.35 & 0.35 & 0.40 & 0.40 & 0.50 \\
\hline & & 2000 & 2001 & 2002 & 2003 & 2004 & 2005 & 2006 & 2007 & 2008 \\
\hline E1 & Appointment & 0 & 0 & 0 & 0 & 0 & 0 & 0 & 0 & 0 \\
\hline E2 & $\begin{array}{l}\text { Auditor } \\
\text { independence }\end{array}$ & 1 & 1 & 1 & 1 & 1 & 1 & 1 & 1 & 1 \\
\hline E3 & Focus & 1 & 1 & 1 & 1 & 1 & 1 & 1 & 1 & 1 \\
\hline $\mathrm{E} 4$ & $\begin{array}{l}\text { Rule-making } \\
\text { power }\end{array}$ & 0 & $1^{\mathrm{n}}$ & 1 & 1 & 1 & 1 & 1 & 1 & 1 \\
\hline E5 & Tenure & 0 & 0 & $1^{o}$ & 1 & 1 & 1 & 1 & 1 & 1 \\
\hline E6 & Document & 0 & $1^{p}$ & 1 & 1 & 1 & 1 & 1 & 1 & 1 \\
\hline E7 & Review & 0 & $0.5^{\mathrm{q}}$ & 0.5 & 0.5 & 0.5 & 0.5 & 0.5 & 0.5 & 0.5 \\
\hline E8 & $\begin{array}{l}\text { Sanctions } \\
\text { company }\end{array}$ & 1 & 1 & 1 & 1 & 1 & 1 & 1 & 1 & 1 \\
\hline E9 & $\begin{array}{l}\text { Sanctions } \\
\text { management }\end{array}$ & 1 & 1 & 1 & 1 & 1 & 1 & 1 & 1 & 1 \\
\hline E10 & $\begin{array}{l}\text { Sworn } \\
\text { statement }\end{array}$ & 1 & 1 & 1 & 1 & 1 & 1 & 1 & 1 & 1 \\
\hline \multirow{2}{*}{\multicolumn{2}{|c|}{ Enforcement score }} & 0.50 & 0.75 & 0.85 & 0.85 & 0.85 & 0.85 & 0.85 & 0.85 & 0.85 \\
\hline & & 2009 & 2010 & 2011 & 2012 & 2013 & 2014 & 2015 & 2016 & 2017 \\
\hline E1 & Appointment & 0 & 0 & 0 & 0 & 0 & 0 & 0 & 0 & 0 \\
\hline E2 & $\begin{array}{l}\text { Auditor } \\
\text { independence }\end{array}$ & 1 & 1 & 1 & 1 & 1 & 1 & 1 & 1 & 1 \\
\hline E3 & Focus & 1 & 1 & 1 & 1 & 1 & 1 & 1 & 1 & 1 \\
\hline $\mathrm{E} 4$ & $\begin{array}{l}\text { Rule-making } \\
\text { power }\end{array}$ & 1 & 1 & 1 & 1 & 1 & 1 & 1 & 1 & 1 \\
\hline
\end{tabular}

Notes: rThe CVM was only allowed to impose warnings or fines according to law 6.385/76 Art. 11. CVM's scope of penalisation power extended by entering into force of law 9.457/97 in 1997. Since then the CVM is also allowed to setup temporary disqualification or cancellation of the registration or the authorisation to carry out the activities covered by the law 6.385/76, Art. 11; Law 9.457/97, Art. 11 (OECD, 2013).

sThe management of listed companies can be made personally liable in the case of deception (Law 6.404/76, Art. 158; Law 10,303/01, Art. 27-C).

tOfficers of a corporation have to affirm the material accuracy of financial statements since 1976 (Law 6.404/76, Art. 177, paragraph 4). 
Table 3 Score values by year, Brazil (continued)

\begin{tabular}{llccccccccc}
\hline & & 2009 & 2010 & 2011 & 2012 & 2013 & 2014 & 2015 & 2016 & 2017 \\
\hline E5 & Tenure & 1 & 1 & 1 & 1 & 1 & 1 & 1 & 1 & 1 \\
E6 & Document & 1 & 1 & 1 & 1 & 1 & 1 & 1 & 1 & 1 \\
E7 & Review & 0.5 & 0.5 & 0.5 & 0.5 & 0.5 & 0.5 & 0.5 & 0.5 & 0.5 \\
E8 & $\begin{array}{l}\text { Sanctions } \\
\text { company }\end{array}$ & 1 & 1 & 1 & 1 & 1 & 1 & 1 & 1 & 1 \\
E9 & $\begin{array}{l}\text { Sanctions } \\
\text { management }\end{array}$ & 1 & 1 & 1 & 1 & 1 & 1 & 1 & 1 & 1 \\
E10 & $\begin{array}{l}\text { Sworn } \\
\text { statement }\end{array}$ & 1 & 1 & 1 & 1 & 1 & 1 & 1 & 1 & 1 \\
\hline Enforcement score & 0.85 & 0.85 & 0.85 & 0.85 & 0.85 & 0.85 & 0.85 & 0.85 & 0.85 \\
\hline
\end{tabular}

Notes: ${ }^{n}$ With the introduction of Law 10.303/01 in 2001 CVM obtained legislative power. Any similar regulations did not exist before [Law 6.385/76 text as determined by Law 10.303/01 Art. 2, (3); Salotti and Carvalho, (2015)].

${ }^{\circ} \mathrm{A}$ member can only be removed from his mandate in the event of non-compliance with his duties or violations within his office, resignation or legal conviction despite criminal and administrative law (Law 10.411/02, Art. 6, (2) and (3)).

pThe Securities Commission of Brazil can seize any relevant document [(OECD, 2013); law regulation 3.995 Art. 9 paragraph I].

qThe CVM is permitted to setup investigations in the event of indications of behaviour violating the law (Law 6.385/76, Art. 9 (I) (b) and (V)).

We assume that laws are the most effective form of regulations. Therefore, we mainly worked with the original legal securities and common law resources or other regulations on a country's stock exchanges. Only if we could not retrieve laws or any other regulations regarding a specific score item was secondary accounting literature used instead. For Brazil, we referred to Law 6.404/76, Law 9.457/97, Law 6.385/76, Law 10.411/02, 4.595/64, 10.303/01, Law 9.457/97, and different CVM Instructions (Table 3). For Russia we found evidence for the score items in Federal Law No. 39 dated April 22nd, 1996, Federal Law on Joint-Stock Companies of December 26th, 1995, Federal Law No. 251-FZ dated July 23rd, 2013, Law No. 46 on the Protection of Investors Rights of March 1999, Federal Law of July 27th, 2010 and Federal law on accounting (Table 4). For India, we uncovered evidence for the regulations in disclosure and enforcement in the Companies Act of 1956 and 2013, Prohibition of Insider Trading Regulations of 1992, Securities Exchange Board of India (SEBI) Act, 1992, Securities Contract Act (SCRA), 1956, SEBI Amendment Act 1995, Securities Law Amendments Act 2004 (Table 5). For China, we used Law of the People's Republic of China (PRC) on Securities, Regulations on Financial Accounting Reports of Enterprises, Company Law of the PRC 2010 and the Law of the PRC on Certified Public Accountants (Table 6). For South Africa, the laws where we identified our regarded score elements are in Companies Act No. 71 of 2008, Companies Act of 1973, Banks Act 1990, and the King Reports I-III (Table 7). Tables 3-7 present every single disclosure and enforcement score for every regarded country over time and provides explanations for value changes within the score. 
Table 4 Score values by year, Russia

\begin{tabular}{llccccccccc}
\hline & 1991 & 1992 & 1993 & 1994 & 1995 & 1996 & 1997 & 1998 & 1999 \\
\hline D1 & $\begin{array}{l}\text { Information } \\
\text { accounting }\end{array}$ & 0 & 0 & 0 & 0 & 0 & 0 & 0 & 0 & 0 \\
D2 & $\begin{array}{l}\text { Management } \\
\text { commentary }\end{array}$ & $0.25^{\mathrm{b}}$ & 0.25 & 0.25 & 0.25 & 0.25 & 0.25 & 0.25 & 0.25 & 0.25 \\
D3 & $\begin{array}{l}\text { Material } \\
\text { information }\end{array}$ & 0 & 0 & 0 & 0 & 0 & $1^{\mathrm{c}}$ & 1 & 1 & 1 \\
D4 & $\begin{array}{l}\text { Quarterly } \\
\text { reports }\end{array}$ & 0 & 0 & 0 & 0 & 0 & 0 & 0 & 0 & $1^{\mathrm{d}}$ \\
D5 & $\begin{array}{l}\text { Segment } \\
\text { information }\end{array}$ & 0 & 0 & 0 & 0 & 0 & 0 & 0 & 0 & 0 \\
D6 & $\begin{array}{l}\text { Compensation } \\
\text { D7 }\end{array}$ & 0 & 0 & 0 & 0 & 0 & 0 & 0 & 0 & 0 \\
Inside & 0 & 0 & 0 & 0 & 0 & $1 \mathrm{~g}$ & 1 & 1 & 1 \\
D8 & $\begin{array}{l}\text { ownership } \\
\text { Prospectus }\end{array}$ & 0 & 0 & 0 & 0 & 0 & $0.5^{\mathrm{h}}$ & 0.5 & 0.5 & 0.5 \\
D9 & $\begin{array}{l}\text { Shareholders } \\
\text { D10 }\end{array}$ & 0 & 0 & 0 & 0 & 0 & 0 & 0 & 0 & 0 \\
\hline Disclosure score & 0.03 & 0.03 & 0.03 & 0.03 & 0.08 & 0.33 & 0.33 & 0.33 & 0.43 \\
\hline
\end{tabular}

Notes: ${ }^{\mathrm{b}}$ The management report can be voluntarily issued if the managing directors and the executive board consider the information contained in the management report to be useful for addressees of the annual financial statements (Ionova and Scholz, 2014).

${ }^{\mathrm{c}}$ Regulations on ad hoc reporting are provided within Federal Law No. 39 dated April 22nd, 1996, Art. 30 as well as in the special regulations for disclosure of the Federal Commission of Securities Market (FCSM). These special regulations prescribe a list of events that have an impact on the share price and need to be reported immediately (FCSM Resolution of August 12th, 1998; Federal Law No.39-FZ of April 22nd, 1996).

dAccording to Polozheniya po Bukhgalterskomu Uchetu (PBU) 4/1999 § 48-49 monthly and quarterly statements are required to complement annual statements. Interim statements consist of a balance sheet and an income statement. Prior to 2002, the financial statements were prepared exclusively for tax purposes. Since January 2002, it has been possible to separate the commercial balance sheet from the profit tax calculation (Ionova and Scholz, 2014). Monthly financial statements are usually not prepared in practice if this is not required for tax purposes (Ionova and Scholz, 2014). There are no material differences to IAS 34 [Semke, (2010); Arrangement of the Ministry of Finance (MoF): RF Nr. 43n dated July 6th, 1999]. gWith the adoption of Federal Law No. 39 in 1996 the disclosure of information on the management's shareholdings became mandatory, which was not requirement before (Federal Law No. 39 of April 22nd, 1996, Art. 30). hThe preparation of a securities prospectus is mandatory for listed companies since 1996 (Federal Law on the Securities Market of April 22nd, 1996). However, company size-related exceptions exist (Gubin and Molotnikov, 2016).

jSince 1995, listed companies are required to unveil transactions of the shareholders who own at least $20 \%$ (Federal Law on Joint-Stock Companies of December 26th 1995, Art. 82). The obligation to disclose transactions with members of the management or board members is regulated by PBU 11. There are according to Federal Law No. 208 on Joint Stock Companies Art. 82 No deviations from IAS 24 (Kurtbedinov, 2008; McGee and Preobragenskaya, 2005). 
Table 4 Score values by year, Russia (continued)

\begin{tabular}{|c|c|c|c|c|c|c|c|c|c|c|}
\hline & & 2000 & 2001 & 2002 & 2003 & 2004 & 2005 & 2006 & 2007 & 2008 \\
\hline D1 & $\begin{array}{l}\text { Information } \\
\text { accounting }\end{array}$ & 0 & 0 & 0 & 0 & 0 & 0 & 0 & 0 & 0 \\
\hline D2 & $\begin{array}{l}\text { Management } \\
\text { commentary }\end{array}$ & 0.25 & 0.25 & 0.25 & 0.25 & 0.25 & 0.25 & 0.25 & 0.25 & 0.25 \\
\hline D3 & $\begin{array}{l}\text { Material } \\
\text { information }\end{array}$ & 1 & 1 & 1 & 1 & 1 & 1 & 1 & 1 & 1 \\
\hline D4 & $\begin{array}{l}\text { Quarterly } \\
\text { reports }\end{array}$ & 1 & 1 & 1 & 1 & 1 & 1 & 1 & 1 & 1 \\
\hline D5 & $\begin{array}{l}\text { Segment } \\
\text { information }\end{array}$ & $1^{\mathrm{e}}$ & 1 & 1 & 1 & 1 & 1 & 1 & 1 & 1 \\
\hline D6 & Compensation & 0 & 0 & $0.5^{\mathrm{f}}$ & 0.5 & 0.5 & 0.5 & 0.5 & 0.5 & 0.5 \\
\hline D7 & $\begin{array}{l}\text { Inside } \\
\text { Ownership }\end{array}$ & 1 & 1 & 1 & 1 & 1 & 1 & 1 & 1 & 1 \\
\hline D8 & Prospectus & 0.5 & 0.5 & 0.5 & 0.5 & 0.5 & 0.5 & 0.5 & 0.5 & 0.5 \\
\hline D9 & Shareholders & 0 & 0 & 0 & 0 & 0 & 0 & $1^{\mathrm{i}}$ & 1 & 1 \\
\hline D10 & Transactions & 1 & 1 & 1 & 1 & 1 & 1 & 1 & 1 & 1 \\
\hline \multirow{2}{*}{\multicolumn{2}{|c|}{ Disclosure score }} & 0.58 & 0.58 & 0.63 & 0.63 & 0.63 & 0.63 & 0.73 & 0.73 & 0.73 \\
\hline & & 2009 & 2010 & 2011 & 2012 & 2013 & 2014 & 2015 & 2016 & 2017 \\
\hline D1 & $\begin{array}{l}\text { Information } \\
\text { accounting }\end{array}$ & 0 & 0 & 0 & $1^{\mathrm{a}}$ & 1 & 1 & 1 & 1 & 1 \\
\hline D2 & $\begin{array}{l}\text { Management } \\
\text { commentary }\end{array}$ & 0.25 & 0.25 & 0.25 & 0.25 & 0.25 & 0.25 & 0.25 & 0.25 & 0.25 \\
\hline
\end{tabular}

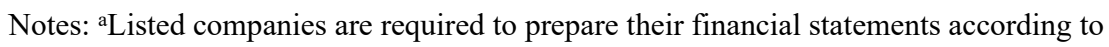
IFRS since 2012. Before 2012 was no regulation allowing voluntary IFRS adoption (Kim, 2016).

ePBU 12/2000 contains regulations on segment reporting and was issued by the direction of the MoF on January 27th, 2000. It is an analogue regulation to the previous IAS 14 before it was amended in 1998 . The standard was revised in line with IFRS 8 Operating Segments as RLS 12/2010 (McGee and Preobragenskaya, 2005). Since 2012, the mandatory adoption of the IFRS prevails.

${ }_{\mathrm{f}}$ According to FCSM regulation "About the information disclosure by the issuers of securities' Art. 8.2.3, it is mandated that the compensation schemes of each member of a governing organ is to be disclosed in annual reports of companies which make public offer of securities (this regulation exists since March 16th, 2005). Since 2012, listed companies with a stock exchange listing are required to disclose compensation figures in their annual reporting (Bogatyrev, 2016). Only the Corporate Governance Code contains recommendations that listed companies should disclose the total amount of remuneration paid to members of the management board (Kurtbedinov, 2008).

iIn October 2010 amendments were made to improve transparency on the securities market. One of the main amendments extends the list of information items about material facts. In addition, rules for the disclosure of capital structure changed substantially: companies are now required to disclose not only the registered owners but also those persons who control, directly or indirectly, at least $5 \%, 10 \%, 15 \%, 20 \%, 25 \%, 30 \%, 50 \%, 75 \%$ or $95 \%$ of voting shares (Federal Law No. 39 of April 22nd, 1996, Art. 30, amended on October 16th, 2006). 
Table 4 Score values by year, Russia (continued)

\begin{tabular}{|c|c|c|c|c|c|c|c|c|c|c|}
\hline & & 2009 & 2010 & 2011 & 2012 & 2013 & 2014 & 2015 & 2016 & 2017 \\
\hline D3 & $\begin{array}{l}\text { Material } \\
\text { information }\end{array}$ & 1 & 1 & 1 & 1 & 1 & 1 & 1 & 1 & 1 \\
\hline D4 & $\begin{array}{l}\text { Quarterly } \\
\text { reports }\end{array}$ & 1 & 1 & 1 & 1 & 1 & 1 & 1 & 1 & 1 \\
\hline D5 & $\begin{array}{l}\text { Segment } \\
\text { information }\end{array}$ & 1 & 1 & 1 & 1 & 1 & 1 & 1 & 1 & 1 \\
\hline D6 & Compensation & 0.5 & 0.5 & 0.5 & 0.5 & 0.5 & 0.5 & 0.5 & 0.5 & 0.5 \\
\hline D7 & $\begin{array}{l}\text { Inside } \\
\text { Ownership }\end{array}$ & 1 & 1 & 1 & 1 & 1 & 1 & 1 & 1 & 1 \\
\hline D8 & Prospectus & 0.5 & 0.5 & 0.5 & 0.5 & 0.5 & 0.5 & 0.5 & 0.5 & 0.5 \\
\hline D9 & Shareholders & 1 & 1 & 1 & 1 & 1 & 1 & 1 & 1 & 1 \\
\hline D10 & Transactions & 1 & 1 & 1 & 1 & 1 & 1 & 1 & 1 & 1 \\
\hline \multirow{2}{*}{\multicolumn{2}{|c|}{ Disclosure score }} & 0.73 & 0.73 & 0.73 & 0.83 & 0.83 & 0.83 & 0.83 & 0.83 & 0.83 \\
\hline & & 1991 & 1992 & 1993 & 1994 & 1995 & 1996 & 1997 & 1998 & 1999 \\
\hline E1 & Appointment & 0 & 0 & 0 & 0 & 0 & 0 & 0 & 0 & 0 \\
\hline E2 & $\begin{array}{l}\text { Auditor } \\
\text { independence }\end{array}$ & 0 & 0 & $1^{1}$ & 1 & 1 & 1 & 1 & 1 & 1 \\
\hline E3 & Focus & $1^{\mathrm{m}}$ & 1 & 1 & 1 & 1 & 1 & 1 & 1 & 1 \\
\hline E4 & $\begin{array}{l}\text { rule-making } \\
\text { power }\end{array}$ & $1^{\mathrm{n}}$ & 1 & 1 & 1 & 1 & 1 & 1 & 1 & 1 \\
\hline E5 & Tenure & $0^{\circ}$ & 0 & 0 & 0 & 0 & 0 & 0 & 0 & 0 \\
\hline E6 & Document & 0 & 0 & 0 & 0 & 0 & 0 & 0 & 0 & 0 \\
\hline E7 & Review & 0 & 0 & 0 & 0 & 0 & 0 & 0 & 0 & 0 \\
\hline
\end{tabular}

Notes: ${ }^{1}$ Requirements for the independence of auditors are specified as compulsory by Temporary Rules on Auditing of December 22nd, 1993, Art. 12 since 1993 (Sucher and Bychkova, 2001; Vanasco et al., 1997).

mThe banking and securities supervisory authorities were organised in separate bodies until 2013 (Rubtsov, 2013). The supervisory authorities were then incorporated into the Bank of Russia through the adoption of Federal Law No. 251-FZ "On Amendments to Certain Legislative Acts of the Russian Federation connected with Transfer of Authorities to Exercise Regulation, Control and Supervision of Financial Markets to the Central Bank of the Russian Federation" on 23rd of July 2013. The Law intends to establish a mega-regulator, based on the Central Bank of Russia, to perform both regulatory and supervisory functions in relation to financial markets. For these purposes all functions and authorities of the FFMS and certain regulatory powers of Russian Ministry of Finance and Russian Government were transferred to the CBR.

${ }^{n}$ Similar to the FCSM, the MoF had the power to regulate capital markets (Pistor and Xu, 2004; Wei, 2016). The Central Bank of Russia, then again, is regulated by Federal Law No. 251-FZ Art. 76 of July 23rd, 2013.

${ }^{\circ}$ The election and dismissal of members of the Bank of Russia are conducted by the government (Federal Law on the Central Bank of the Russian Federation, Art. 5). 
Table 4 Score values by year, Russia (continued)

\begin{tabular}{|c|c|c|c|c|c|c|c|c|c|c|}
\hline & & 1991 & 1992 & 1993 & 1994 & 1995 & 1996 & 1997 & 1998 & 1999 \\
\hline E8 & $\begin{array}{l}\text { Sanctions } \\
\text { company }\end{array}$ & 0 & 0 & 0 & 0 & 0 & $0.5^{\mathrm{r}}$ & 0.5 & 0.5 & 0.5 \\
\hline E9 & $\begin{array}{l}\text { Sanctions } \\
\text { management }\end{array}$ & 0 & 0 & 0 & 0 & 0 & 0 & 0 & 0 & 0 \\
\hline E10 & $\begin{array}{l}\text { Sworn } \\
\text { statement }\end{array}$ & 0 & 0 & 0 & 0 & 0 & 0 & 0 & 0 & 0 \\
\hline \multirow{2}{*}{\multicolumn{2}{|c|}{ Enforcement score }} & 0.20 & 0.20 & 0.30 & 0.30 & 0.30 & 0.35 & 0.35 & 0.35 & 0.35 \\
\hline & & 2000 & 2001 & 2002 & 2003 & 2004 & 2005 & 2006 & 2007 & 2008 \\
\hline E1 & Appointment & 0 & 0 & 0 & 0 & 0 & 0 & 0 & 0 & 0 \\
\hline E2 & $\begin{array}{l}\text { Auditor } \\
\text { independence }\end{array}$ & 1 & 1 & 1 & 1 & 1 & 1 & 1 & 1 & 1 \\
\hline E3 & Focus & 1 & 1 & 1 & 1 & 1 & 1 & 1 & 1 & 1 \\
\hline E4 & $\begin{array}{l}\text { rule-making } \\
\text { power }\end{array}$ & 1 & 1 & 1 & 1 & 1 & 1 & 1 & 1 & 1 \\
\hline E5 & Tenure & 0 & 0 & 0 & 0 & 0 & 0 & 0 & 0 & 0 \\
\hline E6 & Document & 0 & 0 & 0 & 0 & 0 & 0 & 0 & $1 \mathrm{p}$ & 1 \\
\hline E7 & Review & 0 & 0 & 0 & 0 & 0 & 0 & 0 & 0 & 0 \\
\hline E8 & $\begin{array}{l}\text { Sanctions } \\
\text { company }\end{array}$ & 1 & 1 & 1 & 1 & 1 & 1 & 1 & 1 & 1 \\
\hline E9 & $\begin{array}{l}\text { Sanctions } \\
\text { management }\end{array}$ & 0 & 0 & 0 & 0 & 0 & 0 & 0 & 0 & 0 \\
\hline E10 & $\begin{array}{l}\text { Sworn } \\
\text { statement }\end{array}$ & 0 & 0 & 0 & 0 & 0 & 0 & 0 & 0 & 0 \\
\hline \multicolumn{2}{|c|}{ Enforcement score } & 0.40 & 0.40 & 0.40 & 0.40 & 0.40 & 0.40 & 0.40 & 0.50 & 0.50 \\
\hline
\end{tabular}

Notes: PFSFM was entitled to request all necessary documents from companies under investigation (items 3.4, 3.7 of Decree of the FSFM No. 05-16 of July 1st, 2007). The President of Russia signed the Decree "On abolition of the Federal Commission for Securities Markets, amending and recognizing certain acts of the President of Russia as ineffective" on July 25th 2013. Pursuant to the Decree the FCSM was abolished from 1 September 2013. All financial markets regulatory, controlling and supervisory powers of the FCSM were transferred to the Bank of Russia.

rFinally, an overhaul of the FCSM's powers occurred in 1999 with the adoption of the Investor Protection Law, which took effect at the beginning of 2000. FCSM had the power to initiate investigations, but the imposition of fines required an action in court (Law No. 46 on the Protection of Investors Rights of March 1999). This new law allows the FCSM to fine companies that fail to comply with the provisions of the Securities Law or the Investor Protection Law for an amount of up to 10,000 times the minimum wage without having to go through the courts. Fines may be imposed for violating registration requirements, among others, for failing to disclose relevant information and for disseminating misleading information (Pistor and $\mathrm{Xu}, 2004$ ). 
Table 4 Score values by year, Russia (continued)

\begin{tabular}{llccccccccc}
\hline & 2009 & 2010 & 2011 & 2012 & 2013 & 2014 & 2015 & 2016 & 2017 \\
\hline E1 & Appointment & 0 & 0 & 0 & 0 & $0^{\mathrm{k}}$ & 0 & 0 & 0 & 0 \\
E2 & $\begin{array}{l}\text { Auditor } \\
\text { independence }\end{array}$ & 1 & 1 & 1 & 1 & 1 & 1 & 1 & 1 & 1 \\
E3 & Focus & 1 & 1 & 1 & 1 & 0 & 0 & 0 & 0 & 0 \\
E4 & $\begin{array}{l}\text { rule-making } \\
\text { power }\end{array}$ & 1 & 1 & 1 & 1 & 1 & 1 & 1 & 1 & 1 \\
E5 & Tenure & 0 & 0 & 0 & 0 & 0 & 0 & 0 & 0 & 0 \\
E6 & $\begin{array}{l}\text { Document } \\
\text { E7 }\end{array}$ & 1 & 1 & 1 & 1 & 1 & 1 & 1 & 1 & 1 \\
E8 & $\begin{array}{l}\text { Review } \\
\text { Sanctions }\end{array}$ & 1 & 1 & 1 & 1 & 1 & 1 & 1 & 1 & 1 \\
E9 & $\begin{array}{l}\text { Sampany } \\
\text { Sanctions }\end{array}$ & 0 & $1^{\mathrm{s}}$ & 1 & 1 & 1 & 1 & 1 & 1 & 1 \\
E10 & $\begin{array}{l}\text { mwanagement } \\
\text { Statement }\end{array}$ & 0 & 0 & 0 & 0 & $1^{\mathrm{t}}$ & 1 & 1 & 1 & 1 \\
\hline Enforcement score & 0.50 & 0.60 & 0.60 & 0.60 & 0.65 & 0.65 & 0.65 & 0.65 & 0.65 \\
\hline
\end{tabular}

Notes: kThe MoF acted as supervisory authority from 1991 to 1996 . With the passing of the Russian Companies Act in 1996 the FCSM became its successor. Due to a reorganisation of the government, all monitoring functions were transferred to the Federal Financial Markets Service (FFMS) in March 2004 which was responsible for supervision until 2013 (Rubtsov, 2013). In 2013 the Bank of Russia was convened as a new supervisory body. The members are appointed exclusively by the government (Federal Law on the Central Bank of the Russian Federation, Art. 5; Federal Law No. 251-FZ "On Amendments to Certain Legislative Acts of the Russian Federation in conjunction with Transfer of Authorities to Exercise Regulation, Control and Supervision of Financial Markets to the Central Bank of the Russian Federation" dated July 23rd, 2013).

qThe CBR performs reactive tests (Britton and Pratt, 2016).

${ }^{\mathrm{s}}$ The disclosure of misleading information or other deliberate actions prohibited by the legislation of the Russian Federation has been punished by fine or imprisonment throughout the entire observation period [Klepitskij, (2016);

Article 185.3 of the Criminal Code amended in 2010; Federal Law of July 27th, 2010 Art. 5].

tSince 2013, the management of a listed company has to confirm the material correctness of a financial statement by signing these documents (Federal Law on Accounting Art. 10 Nr. 4 paragraph 7). 
Table 5 Score values by year, India

\begin{tabular}{|c|c|c|c|c|c|c|c|c|c|c|}
\hline & & 1991 & 1992 & 1993 & 1994 & 1995 & 1996 & 1997 & 1998 & 1999 \\
\hline D1 & $\begin{array}{l}\text { Information } \\
\text { accounting }\end{array}$ & 0 & 0 & 0 & 0 & 0 & 0 & 0 & 0 & 0 \\
\hline D2 & $\begin{array}{l}\text { Management } \\
\text { commentary }\end{array}$ & 0 & 0 & 0 & 0 & 0 & 0 & 0 & 0 & 0 \\
\hline D3 & $\begin{array}{l}\text { Material } \\
\text { information }\end{array}$ & 0 & 0 & 0 & 0 & 0 & 0 & 0 & 0 & 0 \\
\hline D4 & Quarterly reports & 0 & 0 & 0 & 0 & 0 & 0 & 0 & 0 & 0 \\
\hline D5 & $\begin{array}{l}\text { Segment } \\
\text { information }\end{array}$ & 0 & 0 & 0 & 0 & 0 & 0 & 0 & 0 & 0 \\
\hline D6 & Compensation & 0 & 0 & 0 & 0 & 0 & 0 & 0 & 0 & 0 \\
\hline D7 & Inside ownership & 0 & $1 \mathrm{~g}$ & 1 & 1 & 1 & 1 & 1 & 1 & 1 \\
\hline D8 & Prospectus & 0 & 0 & 0 & 0 & 0 & 0 & 0 & 0 & 0 \\
\hline D9 & Shareholders & 0 & $1^{\mathrm{i}}$ & 1 & 1 & 1 & 1 & 1 & 1 & 1 \\
\hline D10 & Transactions & $1^{\mathrm{j}}$ & 1 & 1 & 1 & 1 & 1 & 1 & 1 & 1 \\
\hline \multicolumn{2}{|c|}{ Disclosure score } & 0.10 & 0.30 & 0.30 & 0.30 & 0.30 & 0.30 & 0.30 & 0.30 & 0.30 \\
\hline & & 2000 & 2001 & 2002 & 2003 & 2004 & 2005 & 2006 & 2007 & 2008 \\
\hline D1 & $\begin{array}{l}\text { Information } \\
\text { accounting }\end{array}$ & 0 & 0 & 0 & 0 & 0 & 0 & 0 & 0 & 0 \\
\hline D2 & $\begin{array}{l}\text { Management } \\
\text { commentary }\end{array}$ & 0 & $1^{b}$ & 1 & 1 & 1 & 1 & 1 & 1 & 1 \\
\hline D3 & $\begin{array}{l}\text { Material } \\
\text { information }\end{array}$ & 0 & 0 & 0 & 0 & 0 & 0 & 0 & 0 & 0 \\
\hline D4 & Quarterly reports & $1^{\mathrm{d}}$ & 1 & 1 & 1 & 1 & 1 & 1 & 1 & 1 \\
\hline
\end{tabular}

Notes: ${ }^{b}$ Corporate governance has become increasingly important in India in recent years.

This was accompanied by two binding declarations on corporate governance issued by the SEBI. SEBI made the recommendations of the working group binding in Clause 49 of the agreement for listed companies. Companies listed in the BSE 200 and S\&P CNX Nifty indices and all newly listed companies have to apply on the clause since March 31st, 2001 (Rani and Mishra, 2009). Clause 49 IV F states that the Management Report should, e.g., address the following topics: opportunities and risks of the company, possible threats, segment information, internal control systems and their functioning.

dOn February 4th, 2000 SEBI issued guidelines requiring interim financial reporting. According to Clause 41 the quarterly and half-yearly and year to date financial results shall be prepared in accordance with the recognition and measurement principles laid down in Accounting Standard 25 (AS 25 - Interim Financial Reporting). AS 25 was published in 2002 and provides further recommendations on how to deal with interim reporting.

gThe disclosure of information of the ownership of a company's shares by its managers is required since 1992 (Clause 49, IV E (iv)).

${ }^{i}$ With the adoption of the ban on insider trading in 1992, managers have to provide personal information in a form on their ownership status (Prohibition of Insider Trading Regulations, 1992, Article 13 (1), (2)).

${ }^{j}$ Every director of a company who is in any way, whether directly or indirectly, concerned or interested in a contract or arrangement, or proposed contract or arrangement, entered into or to be entered into, by or on behalf of the company, shall disclose the nature of his concern or interest at a meeting of the Board of directors. (Companies Act 1956, Art. 299, Ind AS - 18 Related Party and Clause 49). 
Table 5 Score values by year, India (continued)

\begin{tabular}{llccccccccc}
\hline & & 2000 & 2001 & 2002 & 2003 & 2004 & 2005 & 2006 & 2007 & 2008 \\
\hline D5 & $\begin{array}{l}\text { Segment } \\
\text { information }\end{array}$ & 0 & $0^{\mathrm{e}}$ & 0 & 0 & 0 & 0 & 1 & 1 & 1 \\
D6 & $\begin{array}{l}\text { Compensation } \\
\text { D7 }\end{array}$ & $1^{\mathrm{f}}$ & 1 & 1 & 1 & 1 & 1 & 1 & 1 & 1 \\
& $\begin{array}{l}\text { Inside } \\
\text { ownership }\end{array}$ & 1 & 1 & 1 & 1 & 1 & 1 & 1 & 1 & 1 \\
D8 & Prospectus & 0 & 0 & 0 & 0 & 0 & 0 & 0 & 0 & $1^{\mathrm{h}}$ \\
D9 & Shareholders & 1 & 1 & 1 & 1 & 1 & 1 & 1 & 1 & 1 \\
D10 & Transactions & 1 & 1 & 1 & 1 & 1 & 1 & 1 & 1 & 1 \\
\hline Disclosure score & 0.50 & 0.60 & 0.60 & 0.60 & 0.60 & 0.60 & 0.70 & 0.70 & 0.80 \\
\hline & 2009 & 2010 & 2011 & 2012 & 2013 & 2014 & 2015 & 2016 & 2017 \\
\hline D1 & $\begin{array}{l}\text { Information } \\
\text { accounting }\end{array}$ & 0 & $0.5^{\mathrm{a}}$ & 0.5 & 0.5 & 0.5 & 0.5 & 0.5 & 0.5 & 0.5 \\
D2 & $\begin{array}{l}\text { Management } \\
\text { commentary }\end{array}$ & 1 & 1 & 1 & 1 & 1 & 1 & 1 & 1 & 1 \\
D3 & $\begin{array}{l}\text { Material } \\
\text { information }\end{array}$ & 0 & 0 & 0 & 0 & 0 & 0 & $1^{\mathrm{c}}$ & 1 & 1 \\
\hline
\end{tabular}

Notes: aSecurities and Exchange Board of India (SEBI) decided to provide an option for listed companies having subsidiaries to submit their financial statements either in accordance with Ind AS according to Companies Act, 1956, 211 (3C) or in accordance with IFRS (SEBI Circular April 5th, 2010). In January 2015 the Indian MCA issued a revised plan for the launch of Ind AS. Starting with April 1st, companies with net assets exceeding 5.000 million INR are obliged to publish their financial statements according to Ind AS. Companies with net assets below 5.000 million INR but above 2.500 million INR as well as companies listed on foreign stock exchanges have to adopt IFRS, beginning of the financial year 2017. This regulation applies to every company except banks, insurance companies and other financial institutions (Ghio and Verona, 2015).

'SEBI Act of 1992 includes a legal ban on insider trading. However, insider information that has an influence on the buying behaviour of investors has to be transferred to the capital market only since 2015 with the modification of the amendment to the Prohibition of Insider Trading Regulation in 2015. The Code of Fair Disclosure requires companies to report information that affect the share value directly to the capital market (Prohibition of Insider Trading Regulation, Article 8).

'In 2001, the Institute of Chartered Accountants of India (ICAI) implemented the obligation for segment reporting in the standard AS 17 - Segment Reporting (Reddy and Satish, 2001). With the harmonisation to IFRS, Ind AS 108 Operating Segments has been in effect since April 1st, 2011, which requires companies to report both product and service-related segments and geographical segments (Birt et al., 2017).

${ }^{\mathrm{f}}$ All elements of the remuneration structure of the individual members of the management board have to be disclosed under main categories such as salary, benefits, bonuses, stock options and pensions in the annual financial statements [Chakrabarti et al., (2012); Clause 49 IV E (ii), entered into force on February 21st, 2000].

${ }^{\mathrm{h}} \mathrm{A}$ general obligation to prepare securities prospectuses is regulated by Companies Act 2013, Section 26 and Companies Act 1956, Section 56. 
Table 5 Score values by year, India (continued)

\begin{tabular}{llccccccccc}
\hline & & 2009 & 2010 & 2011 & 2012 & 2013 & 2014 & 2015 & 2016 & 2017 \\
\hline D4 & $\begin{array}{l}\text { Quarterly } \\
\text { reports }\end{array}$ & 1 & 1 & 1 & 1 & 1 & 1 & 1 & 1 & 1 \\
D5 & $\begin{array}{l}\text { Segment } \\
\text { information }\end{array}$ & 1 & 1 & 1 & 1 & 1 & 1 & 1 & 1 & 1 \\
D6 & Compensation & 1 & 1 & 1 & 1 & 1 & 1 & 1 & 1 & 1 \\
D7 & $\begin{array}{l}\text { Inside } \\
\text { ownership }\end{array}$ & 1 & 1 & 1 & 1 & 1 & 1 & 1 & 1 & 1 \\
D8 & Prospectus & 1 & 1 & 1 & 1 & 1 & 1 & 1 & 1 & 1 \\
D9 & Shareholders & 1 & 1 & 1 & 1 & 1 & 1 & 1 & 1 & 1 \\
D10 & Transactions & 1 & 1 & 1 & 1 & 1 & 1 & 1 & 1 & 1 \\
\hline Disclosure score & 0.80 & 0.85 & 0.85 & 0.85 & 0.85 & 0.85 & 0.95 & 0.95 & 0.95 \\
\hline & & 1991 & 1992 & 1993 & 1994 & 1995 & 1996 & 1997 & 1998 & 1999 \\
\hline E1 & Appointment & 0 & $0^{\mathrm{k}}$ & 0 & 0 & 0 & 0 & 0 & 0 & 0 \\
E2 & Auditor & $1^{1}$ & 1 & 1 & 1 & 1 & 1 & 1 & 1 & 1 \\
& independence & & & & & & & & & \\
E3 & Focus & $1^{\mathrm{m}}$ & 1 & 1 & 1 & 1 & 1 & 1 & 1 & 1 \\
E4 & Rule-making & 0 & 0 & 0 & 0 & $1^{\mathrm{n}}$ & 1 & 1 & 1 & 1 \\
& power & & & & & & & & & \\
E5 & Tenure & $0^{\mathrm{o}}$ & 0 & 0 & 0 & 0 & 0 & 0 & 0 & 0 \\
E6 & Document & 0 & 0 & 0 & 0 & 0 & 0 & 0 & 0 & 0 \\
E7 & Review & 0 & $0.5^{\mathrm{q}}$ & 0.5 & 0.5 & 0.5 & 0.5 & 0.5 & 0.5 & 0.5 \\
\hline
\end{tabular}

Notes: ${ }^{k}$ The members of the supervisory authority are appointed and elected by the government without exception (SEBI Act, 1992, Art. 4 No. (1) und (4)).

${ }^{1}$ The Companies Act of 1956 gives provisions when an auditor may not be appointed. Since these are rather weak specifications, the score value is set to 0.5 (Companies Act of 1956, Art. 226).

monitoring of the financial system in India is in the responsibility of various supervisory authorities. The Reserve Bank of India (RBI) regulates and monitors most institutions of the financial system. However, investment funds and the equity market are supervised by SEBI and the insurance sector is monitored by the Insurance Regulatory Development Authority of India (IDRA) [Chakrabarti et al., 2008); Securities Contract Act (SCRA), 1956; SEBI Act, 1992].

${ }^{\mathrm{n}} \mathrm{SEBI}$ received legislative power for the first time in 1995. SEBI is authorised to amend the requirements of the listing conditions on the stock exchange and other conditions without further approval of the government [Bhalla (2008); SEBI Amendment Act 1995, Art. 11A, Number 2].

${ }^{\circ}$ The members of the SEBI can only be dismissed by the government. Certain reasons are, e.g., if the member has been convicted of an offence which, in the opinion of the Central Government, involves a moral turpitude; or if the member has, in the opinion of the Central Government, so abused his position as to render his continuation in office detrimental to the public interest (SEBI Act, 1992, Art. 6).

qInvestigations have to take place at the company concerned if there are indications of an infringement (SEBI Act, 1992, Art. 11(C)). 
Table 5 Score values by year, India (continued)

\begin{tabular}{|c|c|c|c|c|c|c|c|c|c|c|}
\hline & & 1991 & 1992 & 1993 & 1994 & 1995 & 1996 & 1997 & 1998 & 1999 \\
\hline E8 & $\begin{array}{l}\text { Sanctions } \\
\text { company }\end{array}$ & 0 & $0.5^{\mathrm{r}}$ & 0.5 & 0.5 & 0.5 & 0.5 & 0.5 & 0.5 & 0.5 \\
\hline E9 & $\begin{array}{l}\text { Sanctions } \\
\text { management }\end{array}$ & $0.5^{\mathrm{s}}$ & 0.5 & 0.5 & 0.5 & 0.5 & 0.5 & 0.5 & 0.5 & 0.5 \\
\hline E10 & $\begin{array}{l}\text { Sworn } \\
\text { statement }\end{array}$ & $1^{\mathrm{t}}$ & 1 & 1 & 1 & 1 & 1 & 1 & 1 & 1 \\
\hline \multirow{2}{*}{\multicolumn{2}{|c|}{ Enforcement score }} & 0.35 & 0.45 & 0.45 & 0.45 & 0.55 & 0.55 & 0.55 & 0.55 & 0.55 \\
\hline & & 2000 & 2001 & 2002 & 2003 & 2004 & 2005 & 2006 & 2007 & 2008 \\
\hline E1 & Appointment & 0 & 0 & 0 & 0 & 0 & 0 & 0 & 0 & 0 \\
\hline E2 & $\begin{array}{l}\text { Auditor } \\
\text { independence }\end{array}$ & 1 & 1 & 1 & 1 & 1 & 1 & 1 & 1 & 1 \\
\hline E3 & Focus & 1 & 1 & 1 & 1 & 1 & 1 & 1 & 1 & 1 \\
\hline E4 & $\begin{array}{l}\text { Rule-making } \\
\text { power }\end{array}$ & 1 & 1 & 1 & 1 & 1 & 1 & 1 & 1 & 1 \\
\hline E5 & Tenure & 0 & 0 & 0 & 0 & 0 & 0 & 0 & 0 & 0 \\
\hline E6 & Document & 0 & 0 & 0 & $1 \mathrm{p}$ & 1 & 1 & 1 & 1 & 1 \\
\hline E7 & Review & 0.5 & 0.5 & 0.5 & 0.5 & 0.5 & 0.5 & 0.5 & 0.5 & 0.5 \\
\hline E8 & $\begin{array}{l}\text { Sanctions } \\
\text { company }\end{array}$ & 0.5 & 0.5 & 0.5 & 0.5 & 0.5 & 0.5 & 0.5 & 0.5 & 0.5 \\
\hline E9 & $\begin{array}{l}\text { Sanctions } \\
\text { management }\end{array}$ & 0.5 & 0.5 & 0.5 & 0.5 & 0.5 & 0.5 & 0.5 & 0.5 & 0.5 \\
\hline E10 & $\begin{array}{l}\text { Sworn } \\
\text { statement }\end{array}$ & 1 & 1 & 1 & 1 & 1 & 1 & 1 & 1 & 1 \\
\hline \multirow{2}{*}{\multicolumn{2}{|c|}{ Enforcement score }} & 0.55 & 0.55 & 0.55 & 0.65 & 0.65 & 0.65 & 0.65 & 0.65 & 0.65 \\
\hline & & 2009 & 2010 & 2011 & 2012 & 2013 & 2014 & 2015 & 2016 & 2017 \\
\hline E1 & Appointment & 0 & 0 & 0 & 0 & 0 & 0 & 0 & 0 & 0 \\
\hline E2 & $\begin{array}{l}\text { Auditor } \\
\text { independence }\end{array}$ & 1 & 1 & 1 & 1 & 1 & 1 & 1 & 1 & 1 \\
\hline E3 & Focus & 1 & 1 & 1 & 1 & 1 & 1 & 1 & 1 & 1 \\
\hline E4 & $\begin{array}{l}\text { Rule-making } \\
\text { power }\end{array}$ & 1 & 1 & 1 & 1 & 1 & 1 & 1 & 1 & 1 \\
\hline
\end{tabular}

Notes: PSEBI has the right to request any documents from a company within an investigation [(Bhalla, 2013); SEBI Amendment Act, 1995, Art. 11, Number (3) (iii)].

rThe company and the persons involved can be held personally liable for offences of the law [Chakrabarti et al., (2012); SEBI Act, 1992, Art. 27 Securities Law Amendments Act 2004 Art. 11].

sIf material information is deliberately not disclosed or false information are knowingly published, the persons involved may be held personally liable (Chakrabarti et al., 2012; Companies Act 1956, Art. 628). Hence, the score value is set to 0.5 .

${ }^{t}$ An authorised chairman or two managers have to sign the financial statements (Companies Act 1956, Art. 217, Number (4) und Companies Act 2013, Art. 134, Number (6)). 
Table 5 Score values by year, India (continued)

\begin{tabular}{llccccccccc}
\hline & & 2009 & 2010 & 2011 & 2012 & 2013 & 2014 & 2015 & 2016 & 2017 \\
\hline E5 & Tenure & 0 & 0 & 0 & 0 & 0 & 0 & 0 & 0 & 0 \\
E6 & Document & 1 & 1 & 1 & 1 & 1 & 1 & 1 & 1 & 1 \\
E7 & Review & 0.5 & 0.5 & 0.5 & 0.5 & 0.5 & 0.5 & 0.5 & 0.5 & 0.5 \\
E8 & $\begin{array}{l}\text { Sanctions } \\
\text { company }\end{array}$ & 0.5 & 0.5 & 0.5 & 0.5 & 0.5 & 0.5 & 0.5 & 0.5 & 0.5 \\
E9 & $\begin{array}{l}\text { Sanctions } \\
\text { management }\end{array}$ & 0.5 & 0.5 & 0.5 & 0.5 & 0.5 & 0.5 & 0.5 & 0.5 & 0.5 \\
E10 & $\begin{array}{l}\text { Sworn } \\
\text { statement }\end{array}$ & 1 & 1 & 1 & 1 & 1 & 1 & 1 & 1 & 1 \\
\hline Enforcement score & 0.65 & 0.65 & 0.65 & 0.65 & 0.65 & 0.65 & 0.65 & 0.65 & 0.65 \\
\hline
\end{tabular}

Table 6 Score values by year, China

\begin{tabular}{llccccccccc}
\hline & 1991 & 1992 & 1993 & 1994 & 1995 & 1996 & 1997 & 1998 & 1999 \\
\hline D1 & $\begin{array}{l}\text { Information } \\
\text { accounting }\end{array}$ & 0 & 0 & 0 & 0 & 0 & 0 & 0 & 0 & 0 \\
D2 & $\begin{array}{l}\text { Management } \\
\text { commentary }\end{array}$ & 0 & $1^{\mathrm{b}}$ & 1 & 1 & 1 & 1 & 1 & 1 & 1 \\
D3 & $\begin{array}{l}\text { Material } \\
\text { information }\end{array}$ & 0 & 0 & 0 & 0 & 0 & 0 & 0 & 0 & 0 \\
D4 & $\begin{array}{l}\text { Quarterly } \\
\text { reports }\end{array}$ & 0 & 0 & 0 & 0 & 0 & 0 & 0 & 0 & 0 \\
D5 & $\begin{array}{l}\text { Segment } \\
\text { information }\end{array}$ & 0 & 0 & 0 & 0 & 0 & 0 & 0 & 0 & 0 \\
D6 & $\begin{array}{l}\text { Compensation } \\
\text { D7 }\end{array}$ & 0 & 0 & 0 & 0 & 0 & 0 & 0 & 0 & 0 \\
Inside & 0 & 0 & 0 & 0 & 0 & 0 & 0 & $0.5 \mathrm{~g}$ & 0.5 \\
D8 & $\begin{array}{l}\text { Prnership } \\
\text { Prospectus }\end{array}$ & 0 & 0 & 0 & $1^{\mathrm{h}}$ & 1 & 1 & 1 & 1 & 1 \\
D10 & Shareholders & 0 & 0 & 0 & 0 & 0 & 0 & 0 & 0 & $0.5^{\mathrm{i}}$ \\
\hline Disclosure score & 0.00 & 0.10 & 0.10 & 0.20 & 0.20 & 0.20 & 0.30 & 0.35 & 0.40 \\
\hline
\end{tabular}

Notes: bListed companies are obliged to prepare a management report since 1992 until today there are no amendments made [Xiao, (1999); Securities Law of the People's Republic of China Art. 61 (1)].

gDirectors supervisors and senior officers have to disclose their holdings of the company's shares (SSE Listing Rules. Art. 3.1.2).

hThe preparation of a securities prospectus is mandatory for listed companies since 1994. (Company Law of the PRC Art. 87 und 88; Company Law 2010 Art. 85 und 86).

iSecurities Law of the PRC Art. 79 and 80 set out provisions but the law does not clearly indicate whether indirect control is also possible. We therefore allocate a score value of 0.5 to the item.

jASBE 36 replaced the original standard of 1997 and is statutory since 2007. 
Table 6 Score values by year, China (continued)

\begin{tabular}{|c|c|c|c|c|c|c|c|c|c|c|}
\hline & & 2000 & 2001 & 2002 & 2003 & 2004 & 2005 & 2006 & 2007 & 2008 \\
\hline D1 & $\begin{array}{l}\text { Information } \\
\text { accounting }\end{array}$ & 0 & 0 & 0 & 0 & 0 & 0 & $0^{\mathrm{a}}$ & 0 & 0 \\
\hline D2 & $\begin{array}{l}\text { Management } \\
\text { commentary }\end{array}$ & 1 & 1 & 1 & 1 & 1 & 1 & 1 & 1 & 1 \\
\hline D3 & $\begin{array}{l}\text { Material } \\
\text { information }\end{array}$ & 0 & 0 & 0 & 0 & 0 & 0 & $1^{c}$ & 1 & 1 \\
\hline D4 & $\begin{array}{l}\text { Quarterly } \\
\text { reports }\end{array}$ & 0 & $1^{\mathrm{d}}$ & 1 & 1 & 1 & 1 & 1 & 1 & 1 \\
\hline D5 & $\begin{array}{l}\text { Segment } \\
\text { information }\end{array}$ & 0 & 0 & 0 & 0 & 0 & 0 & 0 & $1^{\mathrm{e}}$ & 1 \\
\hline D6 & Compensation & 0 & $0.5^{\mathrm{f}}$ & 0.5 & 0.5 & 0.5 & 0.5 & 1 & 1 & 1 \\
\hline D7 & $\begin{array}{l}\text { Inside } \\
\text { ownership }\end{array}$ & 0.5 & 0.5 & 0.5 & 0.5 & 0.5 & 0.5 & 0.5 & 0.5 & 0.5 \\
\hline D8 & Prospectus & 1 & 1 & 1 & 1 & 1 & 1 & 1 & 1 & 1 \\
\hline D9 & Shareholders & 0.5 & 0.5 & 0.5 & 0.5 & 0.5 & 0.5 & 0.5 & 0.5 & 0.5 \\
\hline D10 & Transactions & 1 & 1 & 1 & 1 & 1 & 1 & 1 & 1 & 1 \\
\hline \multirow{2}{*}{\multicolumn{2}{|c|}{ Disclosure score }} & 0.40 & 0.55 & 0.55 & 0.55 & 0.55 & 0.55 & 0.70 & 0.80 & 0.80 \\
\hline & & 2009 & 2010 & 2011 & 2012 & 2013 & 2014 & 2015 & 2016 & 2017 \\
\hline D1 & $\begin{array}{l}\text { Information } \\
\text { accounting }\end{array}$ & 0 & 0 & 0 & 0 & 0 & 0 & 0 & 0 & 0 \\
\hline D2 & $\begin{array}{l}\text { Management } \\
\text { commentary }\end{array}$ & 1 & 1 & 1 & 1 & 1 & 1 & 1 & 1 & 1 \\
\hline
\end{tabular}

Notes: an February 15th, 2006. The Ministry of Finance of the People's Republic of China published a new set of accounting standards. Namely the Accounting Standards for Business Enterprises (ASBE) which are largely in line with IFRS (Ching Chi Heng and Noronha, 2011). All companies listed on Chinese stock exchanges have to adopt ASBE. The application of IFRS as issued by the International Accounting Standards Board (IASB) is not allowed (Rossetti and Verona, 2017). ASBE are constantly being revised and improved in accordance with IFRS in order to maintain and deepen convergence (Peng et al., 2008; Riccardi, 2016).

'All events that may influence the share price and thus an investor's market decision have to be explained in a report to the stock exchange. The causes. current status and possible legal consequences have to be disclosed (Law of the PRC on Securities. Art. 67).

dThe Regulations on Financial Accounting Reports of Enterprises require annually, semi-annually, quarterly and monthly financial statements (Regulations on Financial Accounting Reports of Enterprises Art. 6).

eASBE 35 - Segment reporting indicates that companies have to report on business segments and geographical segments in their annual financial statements. fSince 2001, listed companies are obliged to report the sum of total remuneration for the three highest paid executives and the three highest paid members of the advisory board, including the members of the executive board. The disclosure of management board remuneration was not required for each individual person separately from 2001 to 2005 (CSRC, 2000, 2002). Only since 2006 listed companies have to report each individual member of the management board and the total remuneration of the company as a sum of salary, bonus and other benefits (Conyon and He, 2012; Company Law. Art. 116). 
Table 6 Score values by year, China (continued)

\begin{tabular}{llccccccccc}
\hline & & 2009 & 2010 & 2011 & 2012 & 2013 & 2014 & 2015 & 2016 & 2017 \\
\hline D3 & $\begin{array}{l}\text { Material } \\
\text { information }\end{array}$ & 1 & 1 & 1 & 1 & 1 & 1 & 1 & 1 & 1 \\
D4 & $\begin{array}{l}\text { Quarterly } \\
\text { reports }\end{array}$ & 1 & 1 & 1 & 1 & 1 & 1 & 1 & 1 & 1 \\
D5 & $\begin{array}{l}\text { Segment } \\
\text { information }\end{array}$ & 1 & 1 & 1 & 1 & 1 & 1 & 1 & 1 & 1 \\
D6 & Compensation & 1 & 1 & 1 & 1 & 1 & 1 & 1 & 1 & 1 \\
D7 & $\begin{array}{l}\text { Inside } \\
\text { ownership }\end{array}$ & 0.5 & 0.5 & 0.5 & 0.5 & 0.5 & 0.5 & 0.5 & 0.5 & 0.5 \\
D8 & Prospectus & 1 & 1 & 1 & 1 & 1 & 1 & 1 & 1 & 1 \\
D9 & Shareholders & 0.5 & 0.5 & 0.5 & 0.5 & 0.5 & 0.5 & 0.5 & 0.5 & 0.5 \\
D10 & Transactions & 1 & 1 & 1 & 1 & 1 & 1 & 1 & 1 & 1 \\
\hline Disclosure score & 0.80 & 0.80 & 0.80 & 0.80 & 0.80 & 0.80 & 0.80 & 0.80 & 0.80 \\
\hline & & 1991 & 1992 & 1993 & 1994 & 1995 & 1996 & 1997 & 1998 & 1999 \\
\hline E1 & Appointment & 0 & $0^{\mathrm{k}}$ & 0 & 0 & 0 & 0 & 0 & 0 & 0 \\
E2 & $\begin{array}{l}\text { Auditor } \\
\text { independence }\end{array}$ & 0 & 0 & 1 & 1 & 1 & 1 & 1 & 1 & 1 \\
E3 & Focus & 0 & $1^{\mathrm{m}}$ & 1 & 1 & 1 & 1 & 1 & 1 & 1 \\
E4 & Rule-making & 0 & $1^{\mathrm{n}}$ & 1 & 1 & 1 & 1 & 1 & 1 & 1 \\
E5 & power & & & & & & & & & \\
E6 & Tenure & 0 & $0^{\circ}$ & 0 & 0 & 0 & 0 & 0 & 0 & 0 \\
E7 & Document & 0 & 0 & 0 & 0 & 0 & 0 & 0 & 0 & 0 \\
\hline Review & 0 & 0 & 0 & 0 & 0 & 0 & 0 & 0 & 0 \\
\hline
\end{tabular}

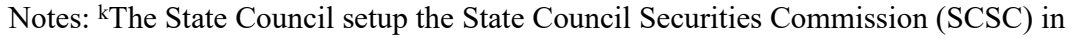
1992 and the China Securities Regulatory Commission (CSRC) was founded in 1993 as a second institution. The two bodies were merged under the CSRC in 1998. The Chairman of the CSRC is also a member of the Council of State by virtue of his office (Pistor and $\mathrm{Xu}, 2004)$. Hence, no attempt has been made to create an independent regulatory authority.

${ }^{1}$ Certified public accountants and public accounting firms have to carry out their business independently and fairly according to law (Law of the PRC on Certified Public Accountants. Art. 6).

mThe CSRC takes over the supervision of the stock exchange and was founded in 1992 (Firth et al., 2014), on April 28th. 2003 China Banking Regulatory

Commission (CBRC) took over the monitoring function of the People's Bank of China (PBOC). The aim of the reform was to improve the efficiency of banking supervision and to help PBOC focusing on monetary policy.

${ }^{n}$ The supervisory authority is empowered by law to formulate rules within the regulation of the securities markets (Securities Law of the PRC. Art. 167. number (1)).

oThe board of directors of CSRC is appointed for a five-year term in office and may serve a second term. The rules governing the dismissal of members of the CSRC do not specify who may dismiss the members. Reasons for a dismissal are given in the Civil Servant Law of the PRC and in the Regulation on the Disciplinary Actions against Civil Servants of Administrative Organs. The element therefore takes the score value 0 over the entire time. 
Table 6 Score values by year, China (continued)

\begin{tabular}{|c|c|c|c|c|c|c|c|c|c|c|}
\hline & & 1991 & 1992 & 1993 & 1994 & 1995 & 1996 & 1997 & 1998 & 1999 \\
\hline E8 & $\begin{array}{l}\text { Sanctions } \\
\text { company }\end{array}$ & 0 & $1^{\mathrm{r}}$ & 1 & 1 & 1 & 1 & 1 & 1 & 1 \\
\hline E9 & $\begin{array}{l}\text { Sanctions } \\
\text { management }\end{array}$ & 0 & 0 & $1^{\mathrm{s}}$ & 1 & 1 & 1 & 1 & 1 & 1 \\
\hline E10 & $\begin{array}{l}\text { Sworn } \\
\text { statement }\end{array}$ & $1^{t}$ & 1 & 1 & 1 & 1 & 1 & 1 & 1 & 1 \\
\hline \multirow{2}{*}{\multicolumn{2}{|c|}{ Enforcement score }} & 0.10 & 0.40 & 0.60 & 0.60 & 0.60 & 0.60 & 0.60 & 0.60 & 0.60 \\
\hline & & 2000 & 2001 & 2002 & 2003 & 2004 & 2005 & 2006 & 2007 & 2008 \\
\hline E1 & Appointment & 0 & 0 & 0 & 0 & 0 & 0 & 0 & 0 & 0 \\
\hline E2 & $\begin{array}{l}\text { Auditor } \\
\text { independence }\end{array}$ & 1 & 1 & 1 & 1 & 1 & 1 & 1 & 1 & 1 \\
\hline E3 & Focus & 1 & 1 & 1 & 1 & 1 & 1 & 1 & 1 & 1 \\
\hline E4 & $\begin{array}{l}\text { Rule-making } \\
\text { power }\end{array}$ & 1 & 1 & 1 & 1 & 1 & 1 & 1 & 1 & 1 \\
\hline E5 & Tenure & 0 & 0 & 0 & 0 & 0 & 0 & 0 & 0 & 0 \\
\hline E6 & Document & 0 & 0 & 0 & 0 & 0 & 0 & $1^{p}$ & 1 & 1 \\
\hline E7 & Review & 0 & 0 & 0 & 0 & 0 & 0 & $0.5^{\mathrm{q}}$ & 0.5 & 0.5 \\
\hline E8 & $\begin{array}{l}\text { Sanctions } \\
\text { company }\end{array}$ & 1 & 1 & 1 & 1 & 1 & 1 & 1 & 1 & 1 \\
\hline E9 & $\begin{array}{l}\text { Sanctions } \\
\text { management }\end{array}$ & 1 & 1 & 1 & 1 & 1 & 1 & 1 & 1 & 1 \\
\hline E10 & $\begin{array}{l}\text { Sworn } \\
\text { statement }\end{array}$ & 1 & 1 & 1 & 1 & 1 & 1 & 1 & 1 & 1 \\
\hline \multirow{2}{*}{\multicolumn{2}{|c|}{ Enforcement score }} & 0.60 & 0.60 & 0.60 & 0.60 & 0.60 & 0.60 & 0.75 & 0.75 & 0.75 \\
\hline & & 2009 & 2010 & 2011 & 2012 & 2013 & 2014 & 2015 & 2016 & 2017 \\
\hline E1 & Appointment & 0 & 0 & 0 & 0 & 0 & 0 & 0 & 0 & 0 \\
\hline E2 & $\begin{array}{l}\text { Auditor } \\
\text { independence }\end{array}$ & 1 & 1 & 1 & 1 & 1 & 1 & 1 & 1 & 1 \\
\hline E3 & Focus & 1 & 1 & 1 & 1 & 1 & 1 & 1 & 1 & 1 \\
\hline E4 & $\begin{array}{l}\text { Rule-making } \\
\text { power }\end{array}$ & 1 & 1 & 1 & 1 & 1 & 1 & 1 & 1 & 1 \\
\hline
\end{tabular}

Notes: PThe securities regulatory authority has the legal right to inspect all documents of a firm under investigation (Securities Law of the PRC. Art. 150 number 3-5). qThere is a rather reactive system which includes investigations only to be carried out if there are special indications as a result of the law (Law of the PRC on Securities. Art. 180). A continuous random sample examination does not exist. rThe CSRC has a wide range of sanction mechanisms (Firth et al., 2014).

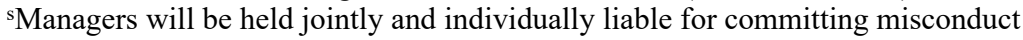
(Firth et al., 2005).

tThe financial accounting statement has to be signed and stamped by the person in charge of the unit, the person in charge of the accounting work and the person in charge of the accounting office (or the accountant-in-charge). If a unit has a chief accountant, it has also be signed and stamped by the chief accountant (Accounting Law of the PRC. Art. 21). 
Table 6 Score values by year, China (continued)

\begin{tabular}{llccccccccc}
\hline & & 2009 & 2010 & 2011 & 2012 & 2013 & 2014 & 2015 & 2016 & 2017 \\
\hline E5 & Tenure & 0 & 0 & 0 & 0 & 0 & 0 & 1 & 1 & 1 \\
E6 & Document & 1 & 1 & 1 & 1 & 1 & 1 & 1 & 1 & 1 \\
E7 & Review & 0.5 & 0.5 & 0.5 & 0.5 & 0.5 & 0.5 & 0.5 & 0.5 & 0.5 \\
E8 & $\begin{array}{l}\text { Sanctions } \\
\text { company }\end{array}$ & 1 & 1 & 1 & 1 & 1 & 1 & 1 & 1 & 1 \\
E9 & $\begin{array}{l}\text { Sanctions } \\
\text { management }\end{array}$ & 1 & 1 & 1 & 1 & 1 & 1 & 0.5 & 0.5 & 0.5 \\
E10 & $\begin{array}{l}\text { Sworn } \\
\text { statement }\end{array}$ & 1 & 1 & 1 & 1 & 1 & 1 & 1 & 1 & 1 \\
\hline Enforcement score & 0.75 & 0.75 & 0.75 & 0.75 & 0.75 & 0.75 & 0.80 & 0.80 & 0.80 \\
\hline
\end{tabular}

Table 7 Score values by year, South Africa

\begin{tabular}{llccccccccc}
\hline & 1991 & 1992 & 1993 & 1994 & 1995 & 1996 & 1997 & 1998 & 1999 \\
\hline D1 & $\begin{array}{l}\text { Information } \\
\text { accounting }\end{array}$ & 0 & 0 & 0 & 0 & $0.5^{\mathrm{a}}$ & 0.5 & 0.5 & 0.5 & 0.5 \\
D2 & $\begin{array}{l}\text { Management } \\
\text { commentary }\end{array}$ & 0 & 0 & 0 & 0 & 0 & 0 & 0 & 0 & 0 \\
D3 & $\begin{array}{l}\text { Material } \\
\text { information }\end{array}$ & 0 & 0 & 0 & 0 & 0 & 0 & 0 & $1^{\mathrm{c}}$ & 1 \\
D4 & $\begin{array}{l}\text { Quarterly } \\
\text { reports } \\
\text { D5 }\end{array}$ & $0.5^{\mathrm{d}}$ & 0.5 & 0.5 & 0.5 & 0.5 & 0.5 & 0.5 & 0.5 & 0.5 \\
Segment & $\begin{array}{l}\text { information } \\
\text { Compensation }\end{array}$ & 0 & 0 & 0 & $0.5^{\mathrm{f}}$ & 0.5 & 0.5 & 0.5 & 0.5 & 0.5 \\
\hline
\end{tabular}

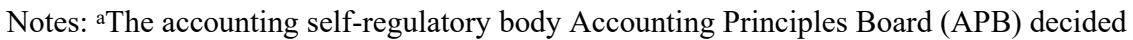
to harmonise South African Generally Accepted Accounting Principles (SA GAAP) with IFRS in 1995. The Council of the South African Institute of Chartered Accountants (SAICA) and the APB promulgate South African accounting standards. SAICA has been adopting IFRS with occasional minor modifications since 1995 and listed companies may follow either SA GAAP or IFRS (Prather-Kinsey, 2006). APB has published the IFRS standards as SA GAAP without amendment in accordance with the due process since 2003. In March 2012, SA GAAP became invalid for financial years beginning on or after December 1st, 2012.

${ }^{\mathrm{c}}$ The JSE listing requirements contain special conditions for precautions which includes an obligation to publish ad hoc information (Vaughn and Ryan, 2006). ${ }^{\mathrm{d} C o m p a n i e s ~ h a v e ~ t o ~ d i s c l o s e ~ s e m i-a n n u a l ~ r e p o r t s . ~ N o ~ m a t e r i a l ~ a m e n d m e n t s ~ w e r e ~}$ made during the observation period (Companies Act Art. 61 of 1973).

${ }^{\mathrm{e} A C} 115$ was effective for periods on July 1st, 1986. With the adoption of IFRS 1 July 1986, companies had to provide more information in line with IAS 14. Since IFRS 8 became statutory in 2009, additional information is required.

fIn 1994, the first King report on corporate governance (King I) was published, which was also the first corporate governance code in South Africa. With King I. the first recommendations were made that companies indicate salaries in total. The merits of the managing directors should be disclosed as a total sum. Commissions should be shown separately. King II required firms for the first time to publish the individual salaries of its directors. Consequently, the King III provisions require that salaries of each director have to be disclosed [Companies Act No. 71 of 2008. Art. 30 (4). (a)]. 
Table $7 \quad$ Score values by year, South Africa (continued)

\begin{tabular}{|c|c|c|c|c|c|c|c|c|c|c|}
\hline & & 1991 & 1992 & 1993 & 1994 & 1995 & 1996 & 1997 & 1998 & 1999 \\
\hline D7 & $\begin{array}{l}\text { Inside } \\
\text { ownership }\end{array}$ & 0 & 0 & 0 & 0 & 0 & 0 & 0 & 0 & 0 \\
\hline D8 & Prospectus & 0 & 0 & 0 & 0 & 0 & 0 & 0 & 0 & 0 \\
\hline D9 & Shareholders & 0 & 0 & 0 & 0 & 0 & 0 & 0 & 0 & 0 \\
\hline D10 & Transactions & 0 & 0 & 0 & 0 & 0 & 0 & 0 & 0 & $1^{\mathrm{j}}$ \\
\hline \multicolumn{2}{|c|}{ Disclosure score } & 0.15 & 0.15 & 0.15 & 0.20 & 0.25 & 0.25 & 0.25 & 0.35 & 0.45 \\
\hline & & 2000 & 2001 & 2002 & 2003 & 2004 & 2005 & 2006 & 2007 & 2008 \\
\hline D1 & $\begin{array}{l}\text { Information } \\
\text { accounting }\end{array}$ & 0.5 & 0.5 & 0.5 & 0.5 & 0.5 & 1 & 1 & 1 & 1 \\
\hline D2 & $\begin{array}{l}\text { Management } \\
\text { commentary }\end{array}$ & 0 & 0 & 0 & 0 & 0 & 0 & 0 & 0 & 0 \\
\hline D3 & $\begin{array}{l}\text { Material } \\
\text { information }\end{array}$ & 1 & 1 & 1 & 1 & 1 & 1 & 1 & 1 & 1 \\
\hline D4 & $\begin{array}{l}\text { Quarterly } \\
\text { reports }\end{array}$ & 0.5 & 0.5 & 0.5 & 0.5 & 0.5 & 0.5 & 0.5 & 0.5 & 0.5 \\
\hline D5 & $\begin{array}{l}\text { Segment } \\
\text { information }\end{array}$ & 1 & 1 & 1 & 1 & 1 & 1 & 1 & 1 & 1 \\
\hline D6 & Compensation & 0.5 & 0.5 & 1 & 1 & 1 & 1 & 1 & 1 & 1 \\
\hline D7 & $\begin{array}{l}\text { Inside } \\
\text { ownership }\end{array}$ & 0 & 0 & 0 & 0 & 0 & 0 & 0 & 0 & 0 \\
\hline D8 & Prospectus & 0 & 0 & 0 & 0 & 0 & 0 & 0 & 0 & $1^{\mathrm{h}}$ \\
\hline D9 & Shareholders & 0 & 0 & 0 & 0 & 0 & 0 & 0 & 0 & $1^{\mathrm{i}}$ \\
\hline D10 & Transactions & 1 & 1 & 1 & 1 & 1 & 1 & 1 & 1 & 1 \\
\hline \multicolumn{2}{|c|}{ Disclosure score } & 0.45 & 0.45 & 0.50 & 0.50 & 0.50 & 0.55 & 0.55 & 0.55 & 0.75 \\
\hline & & 2009 & 2010 & 2011 & 2012 & 2013 & 2014 & 2015 & 2016 & 2017 \\
\hline D1 & $\begin{array}{l}\text { Information } \\
\text { accounting }\end{array}$ & 1 & 1 & 1 & 1 & 1 & 1 & 1 & 1 & 1 \\
\hline D2 & $\begin{array}{l}\text { Management } \\
\text { commentary }\end{array}$ & 0 & $1^{\mathrm{b}}$ & 1 & 1 & 1 & 1 & 1 & 1 & 1 \\
\hline
\end{tabular}

Notes: bThe King Report on Corporate Governance provides guidelines for the governance structures of South African companies and is issued by the King Committee on Corporate Governance. According to the King Code of Governance (King III), companies have to disclose their financial statements as an integrated report. As King III is part of the Johannesburg Stock Exchange (JSE) listing requirements, listed companies have to prepare their financial statements as an integrated report for all business years beginning on March 1st. 2010 (Hindley and Buys, 2012).

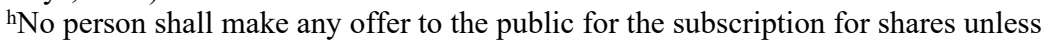
it is accompanied by a prospectus complying with the requirements of the Companies Act and registered in the Companies Registration Office (Companies Act of 1973. Art. 145).

${ }^{\mathrm{i} A}$ direct or indirect owning of 5 percent or more requires the disclosure of personal data (Companies Act of 2008 Art. 122 (1) and (2)).

jIt is required to disclose securities transactions with insiders since 1999 (Oman, 2003). 
Table 7 Score values by year, South Africa (continued)

\begin{tabular}{|c|c|c|c|c|c|c|c|c|c|c|}
\hline & & 2009 & 2010 & 2011 & 2012 & 2013 & 2014 & 2015 & 2016 & 2017 \\
\hline D3 & $\begin{array}{l}\text { Material } \\
\text { information }\end{array}$ & 1 & 1 & 1 & 1 & 1 & 1 & 1 & 1 & 1 \\
\hline D4 & $\begin{array}{l}\text { Quarterly } \\
\text { reports }\end{array}$ & 0.5 & 0.5 & 0.5 & 0.5 & 0.5 & 0.5 & 0.5 & 0.5 & 0.5 \\
\hline D5 & $\begin{array}{l}\text { Segment } \\
\text { information }\end{array}$ & 1 & 1 & 1 & 1 & 1 & 1 & 1 & 1 & 1 \\
\hline D6 & Compensation & 1 & 1 & 1 & 1 & 1 & 1 & 1 & 1 & 1 \\
\hline D7 & $\begin{array}{l}\text { Inside } \\
\text { ownership }\end{array}$ & $1 \mathrm{~g}$ & 1 & 1 & 1 & 1 & 1 & 1 & 1 & 1 \\
\hline D8 & Prospectus & 1 & 1 & 1 & 1 & 1 & 1 & 1 & 1 & 1 \\
\hline D9 & Shareholders & 1 & 1 & 1 & 1 & 1 & 1 & 1 & 1 & 1 \\
\hline D10 & Transactions & 1 & 1 & 1 & 1 & 1 & 1 & 1 & 1 & 1 \\
\hline \multirow{2}{*}{\multicolumn{2}{|c|}{ Disclosure score }} & 0.85 & 0.95 & 0.95 & 0.95 & 0.95 & 0.95 & 0.95 & 0.95 & 0.95 \\
\hline & & 1991 & 1992 & 1993 & 1994 & 1995 & 1996 & 1997 & 1998 & 1999 \\
\hline E1 & Appointment & 0 & 0 & 0 & 0 & 0 & 0 & 0 & 0 & 0 \\
\hline E2 & $\begin{array}{l}\text { Auditor } \\
\text { independence }\end{array}$ & $0.5^{1}$ & 0.5 & 0.5 & 0.5 & 0.5 & 0.5 & 0.5 & 0.5 & 0.5 \\
\hline E3 & Focus & $1^{\mathrm{m}}$ & 1 & 1 & 1 & 1 & 1 & 1 & 1 & 1 \\
\hline E4 & $\begin{array}{l}\text { Rule-making } \\
\text { power }\end{array}$ & 0 & 0 & 0 & 0 & 0 & 0 & 0 & 0 & 0 \\
\hline E5 & Tenure & 0 & 0 & 0 & 0 & 0 & 0 & 0 & 0 & 0 \\
\hline E6 & Document & 0 & 0 & 0 & 0 & 0 & 0 & 0 & 0 & 0 \\
\hline E7 & Review & 0 & 0 & 0 & 0 & 0 & 0 & 0 & 0 & 0 \\
\hline E8 & $\begin{array}{l}\text { Sanctions } \\
\text { company }\end{array}$ & 0 & 0 & 0 & 0 & 0 & 0 & 0 & 0 & 0 \\
\hline E9 & $\begin{array}{l}\text { Sanctions } \\
\text { management }\end{array}$ & $1^{\mathrm{s}}$ & 1 & 1 & 1 & 1 & 1 & 1 & 1 & 1 \\
\hline E10 & $\begin{array}{l}\text { Sworn } \\
\text { statement }\end{array}$ & 0 & 0 & 0 & 0 & 0 & 0 & 0 & 0 & 0 \\
\hline \multicolumn{2}{|c|}{ Enforcement score } & 0.25 & 0.25 & 0.25 & 0.25 & 0.25 & 0.25 & 0.25 & 0.25 & 0.25 \\
\hline
\end{tabular}

Notes: ${ }^{\mathrm{g}}$ Companies have to disclose the ownership structure of the managing directors in line with Art. 30, number (4), letter (d) (Companies Act No. 71 of 2008 was adopted in April 2009).

'The law specifies who is not qualified as an auditor since 1977 with the definition of independence becoming more precise in 2008 (Companies Act 1977 Art. 275. Companies Act 2008 Art. 94 (8), in conjunction with 90, point (2), point (c)). mThe banks are supervised by the Reserve Bank, the stock exchanges by the CIPC (formerly Companies and Intellectual Property Registration Office - CIPRO). Therefore, the supervisory authorities are independent from each other (Banks Act 1990).

sThe management may be fined or imprisoned for grossly negligent misconduct (Companies Act 1973, Section 424; Companies Act 2008, Section 77 (3) (c) and (d)). 
Table 7 Score values by year, South Africa (continued)

\begin{tabular}{llccccccccc}
\hline & 2000 & 2001 & 2002 & 2003 & 2004 & 2005 & 2006 & 2007 & 2008 \\
\hline E1 & Appointment & 0 & 0 & 0 & 0 & 0 & 0 & 0 & 0 & $1^{\mathrm{k}}$ \\
E2 & $\begin{array}{l}\text { Auditor } \\
\text { independence }\end{array}$ & 0.5 & 0.5 & 0.5 & 0.5 & 1 & 1 & 1 & 1 & 1 \\
E3 & Focus & 1 & 1 & 1 & 1 & 1 & 1 & 1 & 1 & 1 \\
E4 & $\begin{array}{l}\text { Rule-making } \\
\text { power }\end{array}$ & 0 & 0 & 0 & 0 & 0 & 0 & 0 & 0 & $0^{\text {n }}$ \\
E5 & Tenure & 0 & 0 & 0 & 0 & 0 & 0 & 0 & 0 & $0^{\mathrm{o}}$ \\
E6 & Document & 0 & 0 & 0 & 0 & 0 & 0 & 0 & 0 & $1^{\mathrm{p}}$ \\
E7 & $\begin{array}{l}\text { Review } \\
\text { E8 }\end{array}$ & 0 & 0 & 0.59 & 0.5 & 0.5 & 0.5 & 0.5 & 0.5 & 0.5 \\
& $\begin{array}{l}\text { Sanctions } \\
\text { company }\end{array}$ & 0 & 0 & 0 & 0 & 0 & 0 & 0 & 0 & $1^{\mathrm{r}}$ \\
E9 & $\begin{array}{l}\text { Sanctions } \\
\text { management }\end{array}$ & 1 & 1 & 1 & 1 & 1 & 1 & 1 & 1 & 1 \\
E10 & $\begin{array}{l}\text { Sworn } \\
\text { statement }\end{array}$ & 0 & 0 & 0 & 0 & 0 & 0 & 0 & 0 & $1^{\mathrm{t}}$ \\
\hline Enforcement score & 0.25 & 0.25 & 0.30 & 0.30 & 0.35 & 0.35 & 0.35 & 0.35 & 0.75 \\
\hline & & 2009 & 2010 & 2011 & 2012 & 2013 & 2014 & 2015 & 2016 & 2017 \\
\hline E1 & $\begin{array}{l}\text { Appointment } \\
\text { E2 }\end{array}$ & 1 & 1 & 1 & 1 & 1 & 1 & 1 & 1 & 1 \\
& $\begin{array}{l}\text { Auditor } \\
\text { independence }\end{array}$ & 1 & 1 & 1 & 1 & 1 & 1 & 1 & 1 & 1 \\
E3 & $\begin{array}{l}\text { Focus } \\
\text { E4 }\end{array}$ & 1 & 1 & 1 & 1 & 1 & 1 & 1 & 1 & 1 \\
& $\begin{array}{l}\text { Rule-making } \\
\text { power }\end{array}$ & 0 & 0 & 0 & 0 & 0 & 0 & 0 & 0 & 0 \\
\hline Notes: & & & & & & & & & & \\
\hline
\end{tabular}

Notes: ${ }^{\mathrm{k}}$ The members of the independent regulatory institution Companies and Intellectual Property Commission (CIPC) are elected by the Minister (Companies Act 2008, Art. 189).

nRegulations on Initial Public Offerings (IPOs) are stated in the Companies Act of 2008, changes may be initiated by the Minister (Art. 95. (7)). The Stock Exchange Rules are directly initiated by JSE. Therefore, the CIPC solely has a monitoring function and cannot adopt rules.

${ }^{\circ}$ There are no regulations regarding the duration of the term of office and the dismissal of members, hence the element takes the score value 0 for the entire observation period.

pThe Commission or the Panel can request any document during an investigation [Schmidt et al., (2011); Companies Act 2008, Art. 176, number (1)].

qUnder the new proactive review procedure, the annual accounts of each listed company are reviewed at least every five years in addition to other issues raised by public or other complaints. Previously, reviews were conducted on the JSE initiative, which received a request or complaint (Schmidt et al., 2011).

rWith the introduction of the Companies Act 2008, the CIPC is entitled to sanction companies (Schmidt et al., 2011).

tThe management confirms the material accuracy by signature [Naidoo, (2009);

Companies Act 71, Art. 30 (3) (c)]. 
Table 7 Score values by year, South Africa (continued)

\begin{tabular}{llccccccccc}
\hline & & 2009 & 2010 & 2011 & 2012 & 2013 & 2014 & 2015 & 2016 & 2017 \\
\hline E5 & Tenure & 0 & 0 & 0 & 0 & 0 & 0 & 0 & 0 & 0 \\
E6 & Document & 1 & 1 & 1 & 1 & 1 & 1 & 1 & 1 & 1 \\
E7 & Review & 0.5 & 0.5 & 1 & 1 & 1 & 1 & 1 & 1 & 1 \\
E8 & $\begin{array}{l}\text { Sanctions } \\
\text { company }\end{array}$ & 1 & 1 & 1 & 1 & 1 & 1 & 1 & 1 & 1 \\
E9 & $\begin{array}{l}\text { Sanctions } \\
\text { management }\end{array}$ & 1 & 1 & 1 & 1 & 1 & 1 & 1 & 1 & 1 \\
E10 & $\begin{array}{l}\text { Sworn } \\
\text { statement }\end{array}$ & 1 & 1 & 1 & 1 & 1 & 1 & 1 & 1 & 1 \\
\hline Enforcement score & 0.75 & 0.75 & 0.80 & 0.80 & 0.80 & 0.80 & 0.80 & 0.80 & 0.80 \\
\hline
\end{tabular}

\section{Results and discussion}

The countries dynamics show effects that institutional theory predicts in form of isomorphism. For the BRICS countries, the increasing similarities of disclosure and enforcement regulation are reflected in our empirical results. All increased their level of disclosure and enforcement over the observation period from 1991 to 2017, which led to higher similarity by way of a decrease in regulatory differences. However, the accounting regulation systems of the five countries still show cross-border differences. At the beginning of the observation period, Brazil - with a disclosure index of 0.33 - expressed the most disclosure requirements, whereas China - at 0.00 - had implemented practically none. The largest increase in disclosure could be found in South Africa, which started at a value of 0.15 in 1991 and rose to a disclosure score of 0.95 in 2015.

Regarding the disclosure scores, the highest number of similarities can be found in the items segment information and transaction. All BRICS countries reached a score value of 1 at the end of the observation period. The highest material difference within the score was revealed in the item information accounting. Russia, India and China still used their national GAAP until 2015.

Figure 1 presents a comparison of the average disclosure score for each country and shows that the disclosure regulation level increased over time. The strong increase in the disclosure regulation supports our hypothesis. The results suggest that emerging countries resort to increasing disclosure regulation. This is an expected and unsurprising result.

A similar pattern can be observed for the enforcement mechanisms: all five countries increased their respective requirements (Figure 2). The average enforcement index rose from 0.25 in 1991 to 0.74 in 2017 . Throughout the analysis period, Russia has had the weakest enforcement system, whereas Brazil has implemented the strongest enforcement system since 2001. The highest development in the enforcement system was made by China, which started at a value of 0.10 in 1991, rising to 0.75 in 2017 . The unique paths, as predicted by institutional theory, are particularly visible, as the enforcement system is more strongly linked with the underlying legal system as is disclosure. This makes path dependencies more pronounced. However, the systems also become more similar eventually. 
Figure 1 Disclosure scores BRICS countries from 1991 to 2017

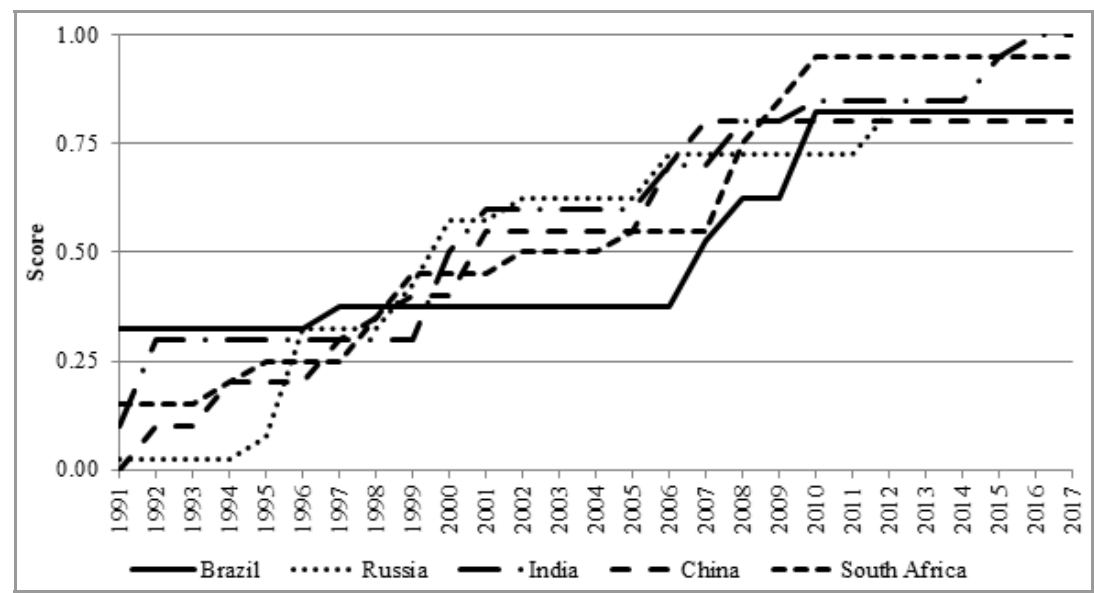

Notes: This figure shows the development of the disclosure scores of all five BRICS countries from 1991 to 2017.0 is the minimum and 1 the maximum value. The scores are based on a leximetric approach (see Table 1 for the score description and Tables 3-7 for the score values).

Figure 2 Enforcement scores BRICS countries from 1991 to 2017

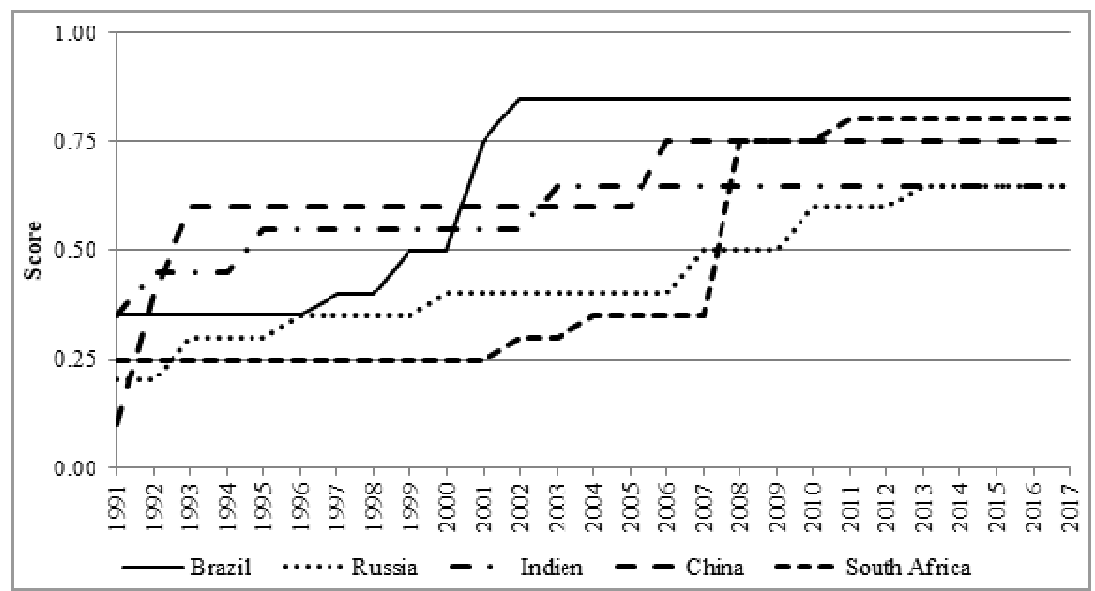

Notes: This figure shows the development of the enforcement scores of all five BRICS countries from 1991 to 2017. 0 is the minimum and 1 the maximum value. The scores are based on a leximetric approach (see Table 1 for the score description and Tables 3-7 for the score values).

Major developments in disclosure take place from 2000, which is why this period deserves special focus. The patterns shown in Figures 1 and 2 provide evidence for our second conjecture on the time and level coupling of disclosure and enforcement. The mean score levels from our sample countries have increased, and faster in disclosure than in enforcement. Regulations in enforcement were implemented with a time delay compared to activities in disclosure. With respect to the different levels, the gap between 
the mean distance of disclosure and enforcement has been increasing since 2006. Our findings are in line with our proposition that disclosure may be the primary area of action due to comparably smaller costs. The identified isomorphic process in accounting regulation can be amplified by the potential need for an international level playing field in accounting regulation and the associated costs imposed due to differences in regulation (Morrison and White, 2009). Figure 3 presents the development of the average disclosure and enforcement scores over time.

Figure 3 Average of disclosure and enforcement score from 1991 to 2017

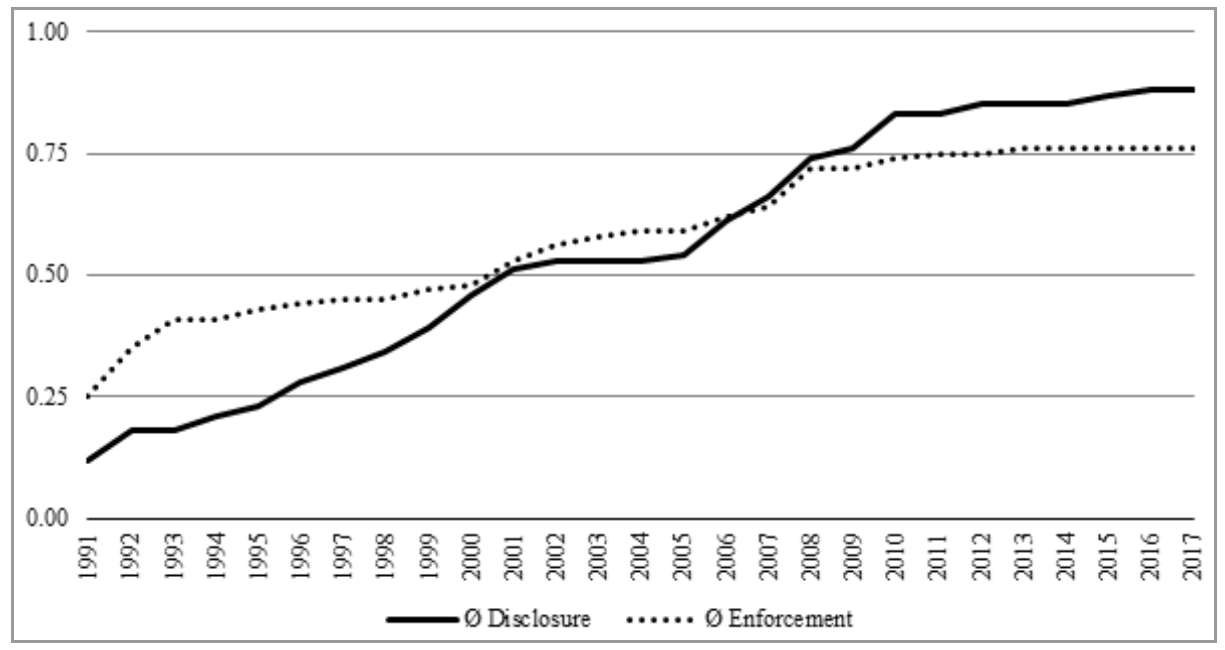

Notes: This figure shows the development of the average disclosure and enforcement scores of all five BRICS countries from 1991 to 2017.0 is the minimum and 1 the maximum value.

\section{Conclusions}

In this paper we considered disclosure and enforcement regulations in BRICS countries from 1991 to 2017. As predicted by institutional theory, the BRICS countries' accounting regulation becomes more similar over time. Isomorphic processes result in accounting convergence. However, substantial differences remain. Path dependencies and institutional rigidities in the respective countries can be identified by institutional theory to play a major role.

We also provide evidence that the increase in enforcement regulation compared to disclosure happened with a slower speed and to a lesser extent. The analysis of the institutional setting in Section 2 shows that this is in line with the difficulties that arise for enforcement regulation. The BRICS countries start their isomorphic efforts partly as label adopters and change their enforcement system only subsequently.

Limitations arise because we only look at regulation of accounting systems at country level (e.g., de jure perspective). The analysis does not fully capture whether regulation actually influences accounting practices at the company level.

There are also opportunities to extend this study. Further research could also use our data to examine the link between regulatory action and international investment flows, 
such as international share ownership or mergers and acquisitions. Moreover, the investigation of regulatory differences between newly industrialised countries and developed countries, e.g., BRICS vs. OECD-countries, might give further interesting insights. The main methodological challenge will be to incorporate the countries' intertemporal institutional change.

\section{References}

Abée, J.S., Meser, M., Veith, S. and Zimmermann, J. (2019) 'Disclosure, enforcement and the valuation of equity', Research Journal of Finance and Accounting, Vol. 10, No. 8, pp.24-60.

Acemoglu, D., Johnson, S. and Robinson, J.A. (2001) 'The colonial origins of comparative development: an empirical investigation', American Economic Review, Vol. 91, No. 5, pp.1369-1401.

Acemoglu, D., Johnson, S. and Robinson, J.A. (2002) 'Reversal of fortune: geography and institutions in the making of the modern world income distribution', The Quarterly Journal of Economics, Vol. 117, No. 4, pp.1231-1294.

Aizenman, J. and Spiegel, M.M. (2006) 'Institutional efficiency, monitoring costs and the investment share of FDI', Review of International Economics, Vol. 14, No. 4, pp.683-697.

Alfaro, L., Kalemli-Ozcan, S. and Volosovych, V. (2005) 'Capital flows in a globalized world: the role of policies and institutions', in Edwards, S. (Ed.): Capital Controls and Capital Flows in Emerging Economies: Policies, Practices, and Consequences, pp.73-120, University of Chicago Press, Chicago.

Alves e Souza, J., Sarlo Neto, A., Carvalho de Benedicto, G. and Mendonça, D.J. (2016) 'Segment reporting in Brazil: factors influencing the disclosure', International Journal of Business Management and Economic Research, Vol. 7, No. 6, pp.804-816.

Armijo, L.E. (2007) 'The BRICs countries (Brazil, Russia, India, and China) as analytical category: mirage or insight?', Asian Perspective, Vol. 31, No. 4, pp.7-42.

Baker, C.R. and Barbu, E.M. (2007) 'Trends in research on international accounting harmonization', The International Journal of Accounting, Vol. 42, No. 3, pp.272-304.

Ball, R. (2001) 'Infrastructure requirements for an economically efficient system of public financial reporting and disclosure', in Litan, R.E. and Herring, R. (Eds.): Brookings-Wharton Papers on Financial Services, pp.127-169, Brookings Institution Press, Washington.

Ball, R. (2006) 'International Financial Reporting Standards (IFRS): pros and cons for investors', Accounting and Business Research, Vol. 36, No. Sup. 1, pp.5-27.

Ball, R., Robin, A. and Wu, J.S. (2003) 'Incentives versus standards: properties of accounting income in four East Asian countries', Journal of Accounting and Economics, Vol. 36, No. 1, pp.235-270.

Barros, L.A.B.d.C., Di Miceli da Silveira, A., Bortolon, P.M. and Leal, R.P.C. (2015) 'Facing the regulators: noncompliance with detailed mandatory compensation disclosure in Brazil', Emerging Markets Finance and Trade, Vol. 51, No. Sup. 2, pp.47-61.

Berkowitz, D., Pistor, K. and Richard, J-F. (2003) 'Economic development, legality, and the transplant effect', European Economic Review, Vol. 47, No. 1, pp.165-195.

Bhalla, V.K. (2013) Investment Management: Security; Analysis and Portfolio Management, 19th ed., S. Chand Publishing, New Delhi.

Biggemann, S. and Fam, K. (2011) 'Business marketing in BRIC countries', Industrial Marketing Management, Vol. 40, No. 1, pp.5-7.

Birt, J., Joshi, M. and Kend, M. (2017) 'Segment reporting in a developing economy: the Indian banking sector', Asian Review of Accounting, Vol. 25, No. 1, pp.127-147.

Bogatyrev, K. (2016) 'Top management compensation and performance in Russian companies', Journal of Corporate Finance Research, Vol. 1, No. 37, pp.5-22. 
Borker, D.R. (2012) 'Accounting, culture, and emerging economies: IFRS in the BRIC countries', International Business \& Economics Research Journal, Vol. 11, No. 9, pp.1003-1018.

Britton, R. and Pratt, R. (2016) 'Report on the observance of standards and codes - IOSCO objectivs and principles of securities regulation', IMF Country Report, Vol. 16, No. 233, pp.1-59.

Brown, P., Preiato, J. and Tarca, A. (2014) 'Measuring country differences in enforcement of accounting standards: an audit and enforcement proxy', Journal of Business Finance \& Accounting, Vol. 41, Nos. 1-2, pp.1-52.

Burgstahler, D., Leuz, C. and Hail, L. (2006) 'The importance of reporting incentives: earnings management in European private and public firms', The Accounting Review, Vol. 81, No. 5, pp.983-1016.

Bushman, R.M., Piotroski, J.D. and Smith, A.J. (2004) 'What determines corporate transparency?', Journal of Accounting Research, Vol. 42, No. 2, pp.207-252.

Carneiro, J., Rodrigues, L.L. and Craig, R. (2017) 'Assessing international accounting harmonization in Latin America', Accounting Forum, Vol. 41, No. 3, pp.172-184.

Chakrabarti, R., Megginson, W. and Yadav, P.K. (2008) 'Corporate governance in India', Journal of Applied Corporate Finance, Vol. 20, No. 1, pp.59-72.

Chakrabarti, R., Subramanian, K., Yadav, P.K. and Yadev, Y. (2012) 'Executive compensation in India', in Thomas, R.S. et al. (Eds.): Research Handbook on Executive Pay, pp.435-465, Edward Elgar Publishing Limited, Cheltenham.

Ching Chi Heng, L. and Noronha, C. (2011) 'The impact of the new Accounting Standards for Business Enterprises (ASBE) on financial results of mainland Chinese listed companies', Advances in Accounting, Vol. 27, No. 1, pp.156-165.

Cissé, H., Bradlow, D.D. and Kingsbury, B. (2012) International Financial Institutions and Global Legal Governance, 3rd ed., The World Bank Legal Review, Washington.

Conyon, M.J. and He, L. (2012) 'Executive compensation and pay performance in China', in Thomas, R.S. et al. (Eds.): Research Handbook on Executive Pay, pp.398-435, Edward Elgar Publishing Limited, Cheltenham.

Cowperthwaite, P. (2010) 'Culture matters: how our culture affects the audit', Accounting Perspectives, Vol. 9, No. 3, pp.175-215.

Daske, H., Hail, L., Leuz, C. and Verdi, R. (2008) 'Mandatory IFRS reporting around the world: early evidence on the economic consequences', Journal of Accounting Research, Vol. 46, No. 5, pp.1085-1142.

Daske, H., Hail, L., Leuz, C. and Verdi, R. (2013) 'Adopting a label: heterogeneity in the economic consequences around IAS/IFRS adoptions', Journal of Accounting Research, Vol. 51, No. 3, pp.495-547.

Deegan, C. (2014) Financial Accounting Theory, 4th ed., McGraw-Hill Education Australia Pty. Ltd., North Ryde NSW.

DiMaggio, P.J. and Powell, W.W. (1983) 'The iron cage revisited: institutional isomorphism and collective rationality in organizational fields', American Sociological Review, Vol. 48, No. 2, pp.147-160.

Ding, Y., Hope, O-K., Jeanjean, T. and Stolowy, H. (2007) 'Differences between domestic accounting standards and IAS: measurement, determinants and implications', Journal of Accounting and Public Policy, Vol. 26, No. 1, pp.1-38.

Doh, J., Rodrigues, S., Saka-Helmhout, A. and Makhija, M. (2017) 'International business responses to institutional voids', Journal of International Business Studies, Vol. 48, No. 3, pp.293-307.

Durnev, A. and Kim, E.H. (2005) 'To steal or not to steal: firm attributes, legal environment, and valuation', The Journal of Finance, Vol. 60, No. 3, pp.1461-1493.

Fan, J.P.H., Wei, K.C.J. and Xu, X. (2011) 'Corporate finance and governance in emerging markets: a selective review and an agenda for future research', Journal of Corporate Finance, Vol. 17, No. 2, pp.207-214. 
Firth, M., Mo, P.L.L. and Wong, R.M.K. (2005) 'Financial statement frauds and auditor sanctions', Journal of Business Ethics, Vol. 62, No. 4, pp.367-381.

Firth, M.A., Mo, P.L.L. and Wong, R.M.K. (2014) 'Auditors' reporting conservatism after regulatory sanctions: evidence from China', Journal of International Accounting Research, Vol. 13, No. 2, pp.1-24.

Francis, J.R., Khurana, I.K. and Pereira, R. (2005) 'Disclosure incentives and effects on cost of capital around the world', The Accounting Review, Vol. 80, No. 4, pp.1125-1162.

Franke, G. (2000) 'Finanzmärkte: Interdependenzen und Entwicklungslinien', in Obst, G. et al. (Eds.): Geld-, Bank-und Börsenwesen, 40th ed., pp.231-270, Schäffer-Poeschel, Stuttgart.

Ghio, A. and Verona, R. (2015) 'Accounting harmonization in the BRIC countries: a common path?', Accounting Forum, Vol. 39, No. 2, pp.121-139.

Gray, S.J. (1988) 'Towards a theory of cultural on the development of accounting influence systems internationally', Abacus, Vol. 24, No. 1, pp.1-15.

Gubin, E. and Molotnikov, A. (2016) Russian Business Law: The Essentials, Lomonosov Moscow State University, Moscow.

Guerreiro, M.S., Rodrigues, L.L. and Craig, R. (2012a) 'Factors influencing the preparedness of large unlisted companies to implement adapted International Financial Reporting Standards in Portugal', Journal of International Accounting, Auditing and Taxation, Vol. 21, No. 2, pp.169-184.

Guerreiro, M.S., Rodrigues, L.L. and Craig, R. (2012b) 'Voluntary adoption of International Financial Reporting Standards by large unlisted companies in Portugal - institutional logics and strategic responses', Accounting, Organizations and Society, Vol. 37, No. 7, pp.482-499.

Hindley, T. and Buys, P.W. (2012) 'Integrated reporting compliance with the global reporting initiative framework: an analysis of the South African mining industry', International Business \& Economics Research Journal, Vol. 11, No. 11, pp.1249-1260.

Hofstede, G. (1980) 'Culture and organizations', International Studies of Management \& Organization, Vol. 10, No. 4, pp.15-41.

Holthausen, R.W. (2009) 'Accounting standards, financial reporting outcomes, and enforcement', Journal of Accounting Research, Vol. 47, No. 2, pp.447-458.

Hope, O.K., Jin, J. and Kang, T. (2006) 'Empirical evidence on jurisdictions that adopt IFRS', Journal of International Accounting Research, Vol. 5, No. 2, pp.1-20.

Hoskisson, R.E., Eden, L., Lau, C.M. and Wright, M. (2000) 'Strategy in emerging economies', The Academy of Management Journal, Vol. 43, No. 3, pp.249-267.

Houqe, M.N. and Monem, R.M. (2016) 'IFRS adoption, extent of disclosure, and perceived corruption: a cross-country study', The International Journal of Accounting, Vol. 51, No. 3, pp.363-378.

Hyun, H.J. (2006) 'Quality of institutions and foreign direct investment in developing countries: causality tests for cross-country panels', Journal of Business Economics and Management, Vol. 7, No. 3, pp.103-110.

Ionova, T. and Scholz, A. (2014) Rechnungslegung in Russland, 2nd ed., Gabler Verlag, Wiesbaden.

Khanna, T. and Palepu, K. (1997) 'Why focused strategies may be wrong for emerging markets', Harvard Business Review, Vol. 75, No. 4, pp.41-51.

Kim, O. (2016) 'The IFRS adoption reform through the lens of neoinstitutionalism: the case of the Russian Federation', The International Journal of Accounting, Vol. 51, No. 3, pp.345-362.

Klepitskij, I. (2016) 'Market manipulation in Russia and in Europe: the criminal law dimension', Russian Law Journal, Vol. 4, No. 3, pp.120-135.

Kurtbedinov, E. (2008) 'Corporate governance: the governance of disclosure regulations', in Krylov, A. and Schauf, T. (Eds.): Internationales Management: Fachspezifische Tendenzen und Best-Practice, pp.211-222, LIT, Berlin. 
La Porta, R., Lopez-De-Silanes, F. and Shleifer, A. (2006) 'What works in securities laws?', The Journal of Finance, Vol. 61, No. 1, pp.1-32.

La Porta, R., Lopez-de-Silanes, F., Shleifer, A. and Vishny, R. (1999) 'The quality of government', Journal of Law, Economics and Organization, Vol. 15, No. 1, pp.222-279.

La Porta, R., Lopez-de-Silanes, F., Shleifer, A. and Vishny, R. (2000) 'Investor protection and corporate governance', Journal of Financial Economics, Vol. 58, Nos. 1/2, pp.3-27.

La Porta, R., Lopez-De-Silanes, F., Shleifer, A. and Vishny, R.W. (1997) 'Legal determinants of external finance', Journal of Finance, Vol. 52, No. 3, pp.1131-1150.

La Porta, R., Lopez-de-Silanes, F., Shleifer, A. and Vishny, R.W. (1998) 'Law and finance', Journal of Political Economy, Vol. 106, No. 6, pp.1113-1155.

Lassou, P.J.C. and Hopper, T. (2016) 'Government accounting reform in an ex-French African colony: the political economy of neocolonialism', Critical Perspectives on Accounting, Vol. 36, No. C, pp.39-57.

Luna, F.V. and Klein, H.S. (2014) The Economic and Social History of Brazil since 1889, Cambridge University Press.

Mahoney, P.G. (2009) 'The development of securities law in the United States', Journal of Accounting Research, Vol. 47, No. 2, pp.325-347.

Makin, A.J. and Arora, R.U. (2014) 'How solid are the BRICS? An economic overview', in Lo, V. and Hiscock, M. (Eds.): The Rise of the BRICS in the Global Political Economy: Changing Paradigms?, pp.11-26, Edward Elgar Publishing, Cheltenham.

MCA (2015) Press Release No. 11/10/2009 CL-V [online]. http://www.mca.gov.in/Ministry/pdf/ PressRelease_06012015.pdf (accessed 8 February 2019).

McGee, R.W. and Preobragenskaya, G.G. (2005) Accounting and Financial System Reform in a Transition Economy, Springer Science, New York.

Meser, M., Veith, S. and Zimmermann, J. (2015) 'Disclosure, enforcement and capital market properties: a longitudinal analysis for Germany', Schmalenbach Business Review, Vol. 67, No. 2, pp.254-287.

Mir, M.Z. and Rahaman, A.S. (2005) 'The adoption of international accounting standards in Bangladesh: an exploration of rationale and process', Accounting, Auditing \& Accountability Journal, Vol. 18, No. 6, pp.816-841.

Morrison, A.D. and White, L. (2009) 'Level playing fields in international financial regulation', The Journal of Finance, Vol. 64, No. 3, pp.1099-1142.

Naidoo, R. (2009) Corporate Governance: An Essential Guide for South African Companies, 2nd ed., LexisNexis, Durban.

Nnadi, M. and Tanna, S. (2019) 'Accounting analyses of momentum and contrarian strategies in emerging markets', Asia-Pacific Journal of Accounting \& Economics, Vol. 26, No. 4, pp.457-477.

Nobes, C.W. and Zeff, S.A. (2008) 'Auditors' affirmations of compliance with IFRS around the world: an exploratory study', Accounting Perspectives, Vol. 7, No. 4, pp.279-292.

North, D.C. (1990) Institutions, Institutional Change and Economic Performace, Cambridge University Press, Cambridge.

OECD (2013) Supervision and Enforcement in Corporate Governance, OECD Publishing, Paris.

Oman, C. (2003) Corporate governance in development: the experiences of Brazil, Chile, India, and South Africa, OECD Publishing and OECD Development Centre, Paris.

Peng, S. and van der Laan Smith, J. (2010) 'Chinese GAAP and IFRS: an analysis of the convergence process', Journal of International Accounting, Auditing and Taxation, Vol. 19, No. 1, pp.16-34.

Peng, S., Tondkar, R.H., van der Laan Smith, J. and Harless, D.W. (2008) 'Does convergence of accounting standards lead to the convergence of accounting practices?: A study from China', The International Journal of Accounting, Vol. 43, No. 4, pp.448-468. 
Pistor, K. and Xu, C-G. (2004) 'Beyond law enforcement: governing financial markets in China and Russia', in Kornai, J. et al. (Eds.): Creating Social Trust in Post-Socialist Transition. Political Evolution and Institutional Change, Palgrave Macmillan, New York.

Prather-Kinsey, J. (2006) 'Developing countries converging with developed-country accounting standards: evidence from South Africa and Mexico', The International Journal of Accounting, Vol. 41, No. 2, pp.141-162.

Rani, D.G. and Mishra, R.K. (2009) Corporate Governance, Excel Books India, New Delhi.

Reddy, Y.V. and Satish, R. (2001) 'Segment reporting in India and abroad - a comparative study', The Indian Journal of Commerce, Vol. 54, Nos. 1/2, pp.19-28.

Riccardi, L. (2016) China Accounting Standards: Introduction and Effects of New Chinese Accounting Standards for Business, Springer, Singapur.

Rodrigues, L.L. and Craig, R. (2007) 'Assessing international accounting harmonization using Hegelian dialectic, isomorphism and Foucault', Critical Perspectives on Accounting, Vol. 18, No. 6, pp.739-757.

Rodrigues, L.L., Schmidt, P. and Santos, J.L.d. (2012) 'The origins of modern accounting in Brazil: influences leading to the adoption of IFRS', Research in Accounting Regulation, Vol. 24, No. 1, pp.15-24.

Rossetti, S. and Verona, R. (2017) 'International differences in IFRS policy choice and the persistence of accounting classification: the case of China', International Journal of Business and Management, Vol. 12, No. 7, pp.27-46.

Rubtsov, B. (2013) 'The Russian securities market: 20 years of development', Protokollband 2013, pp.105-118, Universitätsverlag Potsdam, Potsdam.

Salotti, B. and Carvalho, L.N. (2015) 'Convergence of accounting standards towards IFRS in Brazil', in Lourenço, I. (Ed.): Standardization of Financial Reporting and Accounting in Latin American Countries, pp.79-102, Idea Group, Harrisburg.

Schmidt, R., Sutherland, P., Jacobus van Schalkwyk, C., Lowe, T. and Bockmann, R. (2011) 'Monitoring and enforcement of financial reporting standards in South Africa and Germany: a comparative assessment', Namibian Law Journal, Vol. 36, No. 3, pp.55-83.

Schuster, C.P. (2006) 'Negotiating in BRIC: business as usual isn't', in Jain, S.C. (Ed.): Emerging Economies and the Transformation of International Business. Brazil, Russia, India and China (BRICs), pp.410-427, Edward Elga Publishing, Cheltenham Northampton.

Scott, W.R. (1987) 'The adolescence of institutional theory', Administrative Science Quarterly, Vol. 32, No. 4, pp.493-511.

Semke, N. (2010) Handelsrechtliche Rechnungslegung in Russland im Vergleich zu IFRS, Diplomica Verlag, Hamburg.

Sharma, S., Joshi, M. and Kansal, M. (2017) 'IFRS adoption challenges in developing economies: an Indian perspective', Managerial Auditing Journal, Vol. 32, Nos. 4/5, pp.406-426.

Shleifer, A. and Vishny, R.W. (1993) 'Corruption', Quarterly Journal of Economics, Vol. 108, No. 3, pp.599-617.

Sucher, P. and Bychkova, S. (2001) 'Auditor independence in economies in transition: a study of Russia', European Accounting Review, Vol. 10, No. 4, pp.817-841.

Sunder, S. (1997) Theory of Accounting and Control, South-Western Publishing, Cincinnati.

Themudo Lessa, T.A.D., Lopes Gaspar, R.J., Ferrari Chauffaille, G. and Cervanes de Simoni, V. (2020) 'Brazil', in Putnis, J. (Ed.): The Banking Regulation Review, 11th ed., pp.100-112, Law Business Research Ltd., London.

UNCTAD (2008) Practical Implementation of International Financial Reporting Standards: Lessons Learned: Country Case Studies on IFRS, United Nations, New York.

Vanasco, R.R., Skousen, C.R. and Roger, S.L. (1997) 'Auditor independence: an international perspective', Managerial Auditing Journal, Vol. 12, No. 9, pp.498-505.

Vaughn, M. and Ryan, L.V. (2006) 'Corporate governance in South Africa: a bellwether for the continent?', Corporate Governance: An International Review, Vol. 14, No. 5, pp.504-512. 
Venard, B. and Hanafi, M. (2008) 'Organizational isomorphism and corruption in financial institutions: empirical research in emerging countries', Journal of Business Ethics, Vol. 81, No. 2, pp.481-498.

Wei, S-J. (2000) 'How taxing is corruption on international investors?', The Review of Economics and Statistics, Vol. 82, No. 1, pp.1-11.

Wei, Y. (2016) Securities Markets and Corporate Governance: A Chinese Experience, Taylor \& Francis, London.

Xiao, Z. (1999) 'Corporate disclosures made by Chinese listed companies', The International Journal of Accounting, Vol. 34, No. 3, pp.349-373.

Zeff, S.A. and Nobes, C.W. (2010) 'Commentary: has Australia (or any other jurisdiction) 'adopted' IFRS?', Australian Accounting Review, Vol. 20, No. 2, pp.178-184.

Zeghal, D. and Mhedhbi, K. (2006) 'An analysis of the factors affecting the adoption of international accounting standards by developing countries', The International Journal of Accounting, Vol. 41, No. 4, pp.373-386.

Zimmermann, J. and Tideman, S.A. (2017) 'Accounting convergence and international investment levels', International Journal of Economics and Accounting, Vol. 8, No. 2, pp.138-166.

Zimmermann, J. and Werner, J.R. (2013) Regulating Capitalism? The Evolution of Transnational Accounting Governance, Palgrave Macmillan, Basingstoke.

Zimmermann, J., Werner, J.R. and Volmer, P.B. (2008) Global Governance in Accounting: Rebalancing Public Power and Private Commitment, Palgrave Macmillan, Basingstoke.

\section{Notes}

1 The scope of which countries are characterised as newly industrialised countries differs across definitions from institutions such as the World Bank, OECD, IMF, and EC. We define newly industrialised and emerging countries following the definition of Hoskisson et al. (2000) as "low-income, rapid-growth countries using economic liberalization as their primary engine of growth" and can be generally classified as either developing countries in Asia, Latin America, Africa and the Middle East or as emerging economies as in China or the former Soviet Union (Hoskisson et al., 2000).

2 According to Cowperthwaite (2010) "Culture is to society as personality is to the individual. Each society has a core set of values that it has developed as a response to its own physical and economic situation and to the need to ensure survival. Those values enable people to differentiate between opposites such as good and evil, beauty and ugliness, normal and abnormal, safe and dangerous." 